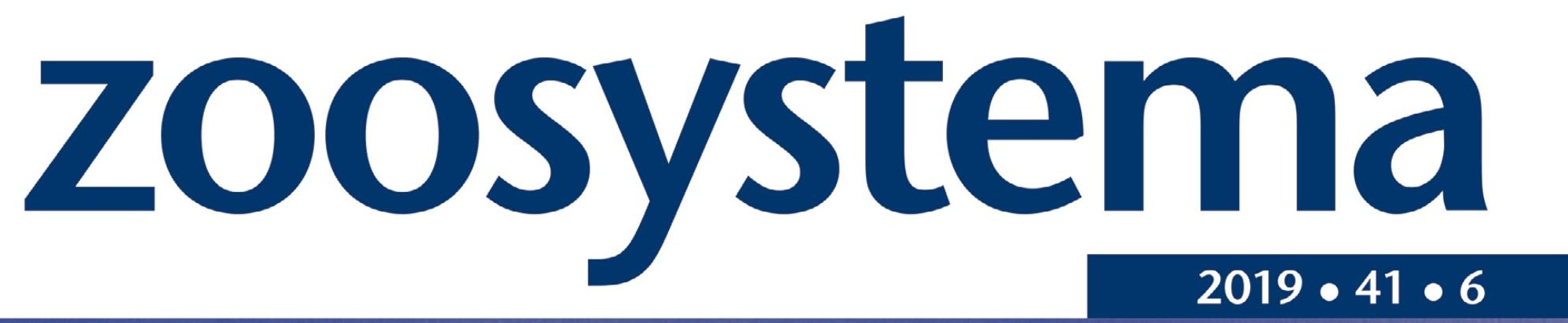

Revisiting Calohypsibiidae and Microhypsibiidae: Fractonotus Pilato, 1998 and its phylogenetic position within Isohypsibiidae (Eutardigrada: Parachela)

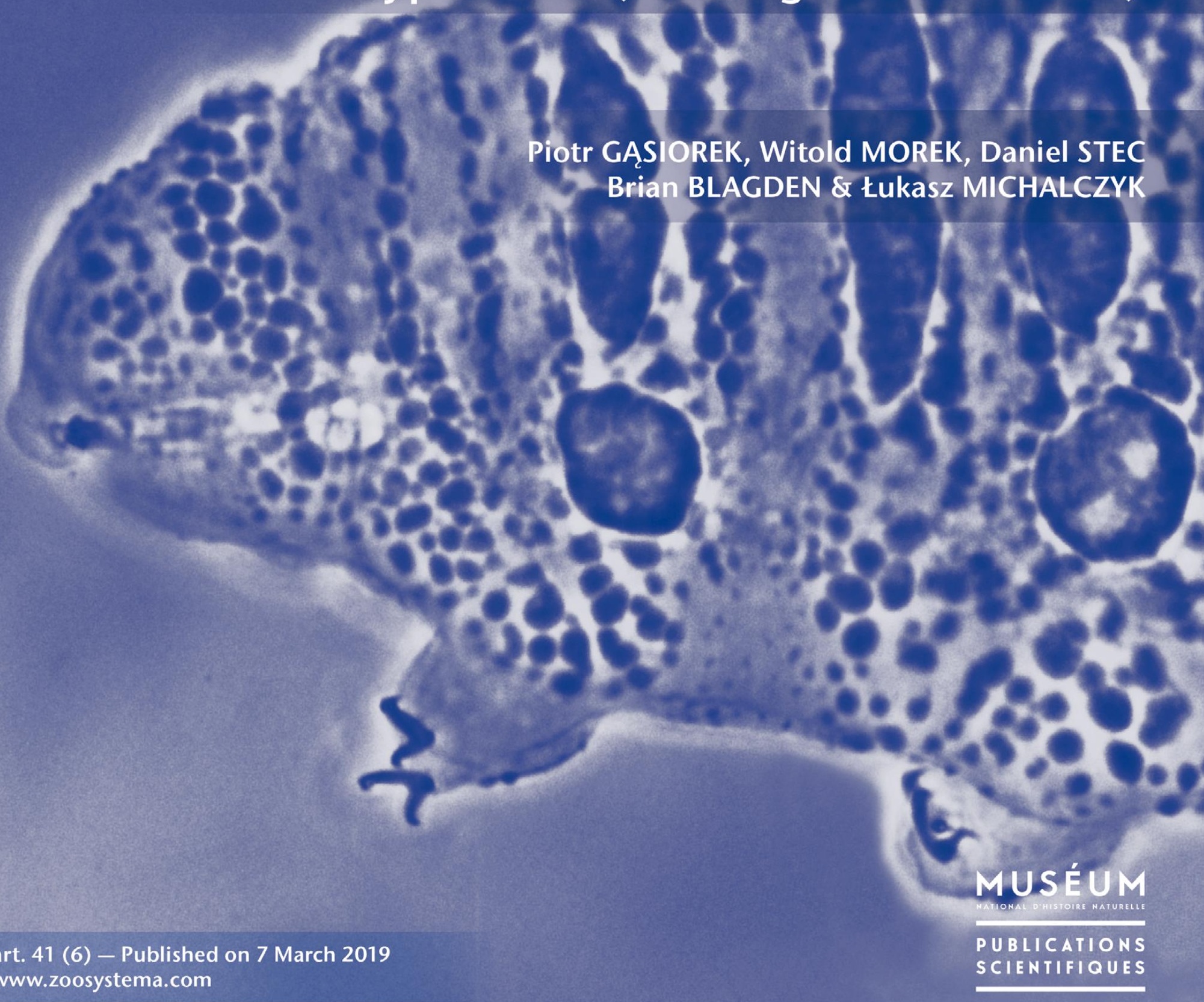


DiRECTEUR DE LA PUBLICATION: Bruno David

Président du Muséum national d'Histoire naturelle

RÉDACTRICE EN CHEF / EDITOR-IN-CHIEF: Laure Desutter-Grandcolas

AssistanTS DE RÉDACTION / AsSISTANT EDITORS: Anne Mabille (zoosyst@mnhn.fr), Emmanuel Côtez

Mise en PAge / Page Layout: Anne Mabille

COMITÉ SCIENTIFIQUE / SCIENTIFIC BOARD:

James Carpenter (AMNH, New York, États-Unis)

Maria Marta Cigliano (Museo de La Plata, La Plata, Argentine)

Henrik Enghoff (NHMD, Copenhague, Danemark)

Rafael Marquez (CSIC, Madrid, Espagne)

Peter $\mathrm{Ng}$ (University of Singapore)

Norman I. Platnick (AMNH, New York, États-Unis)

Jean-Yves Rasplus (INRA, Montferrier-sur-Lez, France)

Jean-François Silvain (IRD, Gif-sur-Yvette, France)

Wanda M. Weiner (Polish Academy of Sciences, Cracovie, Pologne)

John Wenzel (The Ohio State University, Columbus, États-Unis)

COUVERTURE / COVER:

Fractonotus verrucosus (Richters, 1900).

Zoosystema est indexé dans / Zoosystema is indexed in:

- Science Citation Index Expanded (SciSearch ${ }^{\circledR}$ )

- ISI Alerting Services ${ }^{\circledR}$

- Current Contents ${ }^{\circledR} /$ Agriculture, Biology, and Environmental Sciences ${ }^{\circledR}$

- Scopus ${ }^{\circledR}$

Zoosystema est distribué en version électronique par / Zoosystema is distributed electronically by:

- BioOne ${ }^{\circledR}$ (http://www.bioone.org)

Les articles ainsi que les nouveautés nomenclaturales publiés dans Zoosystema sont référencés par / Articles and nomenclatural novelties published in Zoosystema are referenced by:

- ZooBank ${ }^{\circledR}$ (http://zoobank.org)

Zoosystema est une revue en flux continu publiée par les Publications scientifiques du Muséum, Paris / Zoosystema is a fast track journal published by the Museum Science Press, Paris

Les Publications scientifiques du Muséum publient aussi / The Museum Science Press also publish:

Adansonia, Geodiversitas, Anthropozoologica, European Journal of Taxonomy, Naturae, Cryptogamie sous-sections Algologie, Bryologie, Mycologie.

Diffusion - Publications scientifiques Muséum national d'Histoire naturelle

CP $41-57$ rue Cuvier F-75231 Paris cedex 05 (France)

Tél.: 33 (0)1 40794805 / Fax: 33 (0)1 40793840

diff.pub@mnhn.fr/http://sciencepress.mnhn.fr

(c) Publications scientifiques du Muséum national d'Histoire naturelle, Paris, 2019

ISSN (imprimé / print): 1280-9551/ ISSN (électronique / electronic): 1638-9387 


\title{
Revisiting Calohypsibiidae and Microhypsibiidae: Fractonotus Pilato, 1998 and its phylogenetic position within Isohypsibiidae (Eutardigrada: Parachela)
}

\author{
Piotr GASIOREK \\ Witold MOREK \\ Daniel STEC \\ Institute of Zoology and Biomedical Research, Jagiellonian University, \\ Gronostajowa 9, 30-387 Kraków (Poland) \\ Brian BLAGDEN \\ Scottish Environment Protection Agency, Inverdee House, \\ Baxter Street, Aberdeen, AB11 9QA (United Kingdom)
}

Łukasz MICHALCZYK

Institute of Zoology and Biomedical Research, Jagiellonian University, Gronostajowa 9, 30-387 Kraków (Poland)

LM@tardigrada.net (corresponding author)

KEY WORDS

Bucco-pharyngeal apparatus,

claws,
cuticle,

morphology,

phylogeny,

new synonyms,

new combinations.
Gasiorek P., Morek W. Stec D., Blagden B. \& Michalczyk Ł. 2019 - Revisiting Calohypsibiidae and Microhypsibiidae: Fractonotus Pilato, 1998 and its phylogenetic position within Isohypsibiidae (Eutardigrada: Parachela). Zoosystema 41 (6): 71-89. https://doi.org/10.5252/zoosystema2019v41a6. http://zoosystema.com/41/6

\section{ABSTRACT}

Tardigrades constituting the order Parachela are characterised by a generally uniform, worm-like external morphology. Taxa with larger, well-pronounced dorsal cuticular protuberances, tubercles and spines are found in seven genera representing various evolutionary lineages within Hypsibioidea and Isohypsibioidea: Calohypsibius Thulin, 1928 (Calohypsibiidae), Fractonotus Pilato, 1998 (Microhypsibiidae), Ramazzottius Binda \& Pilato, 1986 (Ramazzottiidae), Hypsibius Ehrenberg, 1848 and Pilatobius Bertolani, Guidetti, Marchioro, Altiero, Rebecchi \& Cesari, 2014 (Hypsibiidae), and Doryphoribius Pilato, 1969 and Isohypsibius Thulin, 1928 (Isohypsibiidae). Here, we present the first integrative analysis of a rare eutardigrade species, Calohypsibius verrucosus (Richters, 1900), classified until now within the superfamily Hypsibioidea. The species, having a strongly sculptured cuticle, only superficially resembles Calohypsibius but the modified Isohypsibius-type claws and the morphology of the buccal apparatus place it in a different genus, Fractonotus. The genus is currently classified within the family Microhypsibiidae and superfamily Hypsibioidea, but the first molecular data for Fractonotus show that it should be transferred to the family Isohypsibiidae within the superfamily Isohypsibioidea. We also show ontogenetic variability in cuticle morphology, which, together with the high intraspecific variability of $F$ verrucosus n. comb., allowed us to designate Calohypsibius placophorus (da Cunha, 1943) as a junior synonym of the former species. Furthermore, an analysis of type specimens of Isohypsibius gilvus Biserov, 1986 demonstrated its affinity to the revised Fractonotus. Finally, the diagnoses for Microhypsibiidae, Calohypsibiidae, Calohypsibius and Fractonotus are amended and claw morphology is suggested as a key trait for disentangling phyletic affinities within Isohypsibiidae sensu lato. 
MOTS CLÉS

Appareil bucco-pharyngé,
griffes,
cuticule,
morphologie,
phylogénie,

\begin{abstract}
RÉSUMÉ
Réexamen des Calohypsibiidae et Microhypsibiidae: Fractonotus Pilato, 1998 et sa position phylogénétique au sein des Isohypsibiidae (Eutardigrada: Parachela).

Les Tardigrades qui forment l'ordre des Parachela sont caractérisés par une morphologie externe vermiforme, généralement uniforme. Des taxons avec des protubérances cuticulaires dorsales de grande taille et très marquées, des tubercules et des épines se trouvent dans sept genres représentant plusieurs lignées évolutives au sein des Hypsibioidea et des Isohypsibioidea: Calohypsibius Thulin, 1928 (Calohypsibiidae), Fractonotus Pilato, 1998 (Microhypsibiidae), Ramazzottius Binda \& Pilato, 1986 (Ramazzottiidae), Hypsibius Ehrenberg, 1848 et Pilatobius Bertolani, Guidetti, Marchioro, Altiero, Rebecchi \& Cesari, 2014 (Hypsibiidae), et Doryphoribius Pilato, 1969 et Isohypsibius Thulin, 1928 (Isohypsibiidae). Dans le présent article, nous présentons la première analyse intégrative d'une espèce rare d'eutardigrade, Calohypsibius verrucosus (Richters, 1900), classée jusqu’à présent dans la superfamille des Hypsibioidea. L'espèce ne ressemble que superficiellement à Calohypsibius par sa cuticule très ornée, mais ses griffes très modifiées de type Isohypsibius, et la morphologie de son appareil buccal la placent dans un genre différent, Fractonotus. Ce genre est actuellement classé dans la famille des Microhypsibiidae et la superfamille des Hypsibioidea, mais les premières données moléculaires obtenues pour Fractonotus montrent qu'il faudrait le transférer dans la famille des Isohypsibiidae de la superfamille des Isohypsibioidea. Nous montrons également la variabilité ontogénétique dans la morphologie de la cuticule, ce qui, en plus de la très forte variabilité intraspécifique de F. verrucosus n. comb., nous permet de désigner Calohypsibius placophorus (da Cunha, 1943) comme un synonyme plus récent de l'espèce précédente. Par ailleurs, l'analyse des spécimens types de Isohypsibius gilvus Biserov, 1986 montre sa parenté avec Fractonotus. Finalement, la diagnose des Microhypsibiidae, des Calohypsibiidae, de Calohypsibius et de Fractonotus est amendée et nous suggérons que la morphologie des griffes pourrait constituer un caractère clé pour démêler les parentés phylogénétiques au sein des Isohypsibiidae sensu lato.
\end{abstract}

\section{INTRODUCTION}

Tardigrades, a phylum of microinvertebrates belonging to the clade Panarthropoda (Campbell et al. 2011), are widely distributed in marine, limnic, and terrestrial habitats. Limno-terrestrial species inhabit rivers, lakes, mosses, liverworts, lichens, algae, leaf litter, soil and cryoconite (Nelson et al. 2015; Zawierucha et al. 2015). Among them, members of the relatively uncommon and poor in species family Calohypsibiidae Pilato, 1969 are found exclusively in mosses and lichens. This group, with adults rarely exceeding $200 \mu \mathrm{m}$, comprises particularly small eutardigrades. Pilato (1989) distinguished two main phyletic lineages within the family: one with reduced claws and the other with small, but not reduced claws. The family has probably the most interesting history in terms of taxonomic changes among Eutardigrada. Established in 1969 by Pilato, it comprised four genera, being the second most genus-rich family after Hypsibiidae (with five genera) at that time, a status it held for only a short period. Pilato \& Beasley (1987) described the fifth genus, Haplohexapodibius, yet at this time Hypsibiidae Pilato, 1969 had become a very speciose and genus-rich family, and the family Macrobiotidae Thulin, 1928 had just started to increase in the number of genera (see Degma \& Guidetti 2007; Degma et al. 2009-2017). Problems with classifying calohypsibiid genera, partly due to the variable degree of claw reduction, reached its zenith later, when morphological analyses by Guil et al. (2013) seemed to confirm the monophyly of Calohypsibiidae, whereas a molecular phylogenetic analysis by Bertolani et al. (2014a) resulted in splitting the family into two distinct lineages: Calohypsibiidae s.s. within Hypsibioidea, and the remaining four genera within Isohypsibioidea. The discrepancy between these studies was resolved by Cesari et al. (2016), who, having ascertained the phyletic affinities of Hexapodibius Pilato, 1969 and Haplomacrobiotus May, 1948 within Isohypsibioidea, erected the family Hexapodibiidae.

Thanks to finding abundant populations of Calohypsibius verrucosus (Richters, 1900), an otherwise extremely rare eutardigrade species, we were able to - for the first time - analyse the fine morphology and obtain molecular data for this species. Specifically, both phase contrast light microscope (PCM) and scanning electron microscope (SEM) images of external morphology, as well as of the buccal apparatus are presented and compared with that of other calohypsibiids sensu stricto. The $18 \mathrm{~S}$ and $28 \mathrm{~S}$ rRNA sequences, together with morphological evidence, unequivocally placed the taxon among Isohypsibiidae sensu lato, and suggested placing both Calohypsibius verrucosus and Isohypsibius gilvus Biserov, 1986 within the genus Fractonotus Pilato, 1998. The integrative analyses also allowed us to confirm that $C$. verrucosus and $C$. placophorus (da Cunha, 1943) are not separate taxa but represent different ontogenetic stages of a single species. Finally, the transfer of C. verrucosus to Fractonotus, and of Fractonotus to a different superfamily makes both Calohypsibiidae and Microhypsibiidae monophyletic, explicitly underlying the importance of SEM and DNA analyses in tardigrade taxonomy, especially in species with small body size such as calohypsibiids, where light microscope analyses of phylogenetically important traits, such as minute claws, may lead to erroneous conclusions. An integrative approach is, therefore, shown to be a necessary solution for resolving the systematics of this group. 


\section{MATERIAL AND METHODS}

\section{SAMPLES AND SPECIMENS}

We analysed 40 individuals classified as Calohypsibius placophorus and C. verrucosus, all isolated from three lichen or mixed moss and lichen samples, collected from rocks in mainland Scotland by BB, and from the Outer Hebrides by Shona Morrison in 2014 and 2015 (for exact localities, please see the Results below), and processed following the protocol described by Stec et al. (2015). Of the 40 specimens, 26 were examined under PCM in order to study their external and internal morphology as well as morphometry. SEM was used to investigate the fine details of the external morphology of a further four animals and the buccal apparatuses extracted from another five specimens. The remaining five specimens from all three populations were first checked under PCM and then used for DNA extraction (four of these individuals had cuticular plaques - strongly sclerotised structures resembling pebbles - whereas one was devoid of these structures, i.e. the specimens corresponded with original descriptions of $C$. placophorus and $C$. verrucosus, respectively).

Additionally, several calohypsibiid and microhypsibiid taxa were analysed using PCM or differential interference contrast microscope (DIC): a paratype of C. maliki Michalczyk \& Kaczmarek, 2005; specimens of $C$. ornatus and Fractonotus caelatus (Marcus, 1928) collected by Paulina Kosztyła in Boisle-Roi, France ( $48^{\circ} 27^{\prime} 45^{\prime \prime} \mathrm{N}, 2^{\circ} 39^{\prime} 36^{\prime \prime} \mathrm{E} ; 101 \mathrm{~m}$ a.s.l., moss from stone in a forest) on the $6^{\text {th }}$ February 2016; specimens of C. schusteri Nelson \& McGlothlin, 1996 collected in the Bieszczady Mts., Poland (see Michalczyk \& Kaczmarek 2003 for details); two specimens of $C$. verrucosus from the Thulin collection, deposited in the Natural History Museum of Denmark in Copenhagen, collected in Borgholm, Öland, Sweden; and a single female of Microhypsibius truncatus Thulin, 1928 from Læsø (Kattegat, Denmark), deposited in the Natural History Museum of Denmark in Copenhagen. Two Isohypsibius spp. were used for morphological comparisons (both PCM and SEM): Isohypsibius coulsoni Kaczmarek, Zawierucha, Smykla \& Michalczyk, 2012 from locus typicus, and Isohypsibius prosostomus Thulin, 1928 collected by PG in the Tatra Mts., Poland (49 $14{ }^{\prime} 49^{\prime \prime} \mathrm{N}, 20^{\circ} 05^{\prime} 42^{\prime \prime} \mathrm{E}$; $1037 \mathrm{~m}$ a.s.l., moss from tree bark in upper forest zone) on the 22nd May 2016. Moreover, eight paratypes of Isohypsibius gilvus, deposited in the Department of Animal Biology (University of Modena and Reggio Emilia, Modena), were examined under PCM. Additionally, C. ornatus (Richters, 1900) was analysed by SEM imaging and DNA sequencing.

\section{MiCROSCOPY AND IMAGING}

Specimens for light microscopy and morphometry were mounted on microscope slides in Hoyer's medium according to the recipe and mounting protocol in Morek et al. (2016a), and then examined under a Nikon Eclipse 50i phase-contrast microscope fitted with a Nikon Digital Sight DS-L2 digital camera. Specimens for imaging by SEM were prepared according to Stec et al. (2015). Buccal apparatuses were extracted following a sodium hypochlorite $(\mathrm{NaClO})$ protocol by EibyeJacobsen (2001) with modifications described thoroughly in Gąsiorek et al. (2016). Both animals and apparatuses were examined under high vacuum in a Versa 3D DualBeam SEM at the ATOMIN facility of Jagiellonian University, Kraków, Poland. For deep structures that could not be fully focused in a single photograph, a series of 2-6 images were taken every c. $0.2 \mu \mathrm{m}$ and then assembled with Corel into a single deep-focus image.

\section{MORPHOMETRICS}

The sample size for morphometrics was chosen following the recommendations of Stec et al. (2016). All measurements are given in micrometres $(\mu \mathrm{m})$. Structures were measured only if their orientations were suitable. Body length was measured from the anterior to the posterior end of the body, excluding the hind legs. Terminology for the structures within the buccal apparatus and for the claws follows that of Pilato \& Binda (2010) and Gąsiorek et al. (2017). Gibbosity denotation system by Michalczyk \& Kaczmarek (2010) was applied to the plaque arrangement. Claws were measured following Beasley et al. (2008). The $p t$ ratio is the ratio of the length of a given structure to the length of the buccal tube, expressed as a percentage (Pilato 1981) and is presented here in italics. Morphometric data were handled using version 1.2 of the 'Parachela' template, which is available from the Tardigrada Register (Michalczyk \& Kaczmarek 2013).

\section{GENOTYPING}

DNA was extracted from individual animals using Chelex ${ }^{\oplus}$ 100 resin (Casquet et al. 2012; Stec et al. 2015). We sequenced three DNA fragments that differed in their effective mutation rates: a small ribosome subunit (18S rRNA), a large ribosome subunit (28S rRNA), and internal transcribed spacer (ITS-2). We also attempted to sequence DNA for the cytochrome c oxidase subunit I (COI) but we failed to obtain informative sequences despite trying different primers and their combinations. The three nuclear fragments were amplified and sequenced according to the protocols described by Stec et al. (2015); primers and original references for specific PCR programs are listed in Table 1. Sequencing products were read with the ABI 3130xl sequencer at the Molecular Ecology Laboratory of the Institute of Environmental Sciences at Jagiellonian University. Sequences were processed using version 7.2.6.1 of BioEdit (Hall 1999).

\section{Phylogenetic ANALYSES}

We aligned all available isohypsibioid, hypsibioid, and two Milnesium spp. (outgroup) 18S rRNA sequences (see Table 2) using the default settings of MAFFT version 7 (Katoh et al. 2002; Katoh \& Toh 2008). The obtained alignment was edited and checked manually in BioEdit and then trimmed to 782 bp. Using PartitionFinder version 2.1.1 (Lanfear et al. 2016) under the Bayesian Information Criterion (BIC), the best substitution model was chosen for posterior phylogenetic analysis. First we ran the analysis to test all possible models implemented in the program and the best fit-model was: 
TABLE 1. - Primers and references for specific protocols for amplification of the three DNA fragments sequenced in the study.

\begin{tabular}{llllll}
\hline \multirow{2}{*}{ DNA fragment } & Primer name & \multicolumn{2}{c}{$\begin{array}{l}\text { Primer } \\
\text { direction Primer sequence (5'-3') }\end{array}$} & Primer source & PCR program \\
\hline 18S rRNA & SSU01_F & forward & AACCTGGTTGATCCTGCCAGT & Sands et al. (2008) & Zeller (2010) \\
& SSU82_R & reverse & TGATCCTTCTGCAGGTTCACCTAC & \\
\hline 28S rRNA & 28S_Eutar_F & forward & ACCCGCTGAACTTAAGCATAT & Gąsiorek et al. (2018) Mironov et al. (2012) \\
& 28SR0990 & reverse & CCTTGGTCCGTGTTTCAAGAC & Mironov et al. (2012) \\
\hline ITS-2 & ITS2_Eutar_Ff & forward & CGTAACGTGAATTGCAGGAC & Stec et al. (2018) & Stec et al. (2018) \\
& ITS2_Eutar_Rr & reverse & TGATATGCTTAAGTTCAGCGG & & \\
\hline
\end{tabular}

TABLE 2. - List of the GenBank accession numbers for isohypsibioid, hypsibioid and outgroup DNA sequences used for phylogenetic analyses in the present study (new sequences are marked in bold).

\begin{tabular}{|c|c|c|}
\hline Taxon & 18S rRNA & Reference \\
\hline \multicolumn{3}{|l|}{ Isohypsibioidea } \\
\hline $\begin{array}{l}\text { Apodibius confusus Dastych, } \\
1983\end{array}$ & KC582830 & Dabert et al. (2014) \\
\hline $\begin{array}{l}\text { Fractonotus verrucosus } \\
\text { (Richters, 1900) n. comb. }\end{array}$ & MG800855 & present study \\
\hline Doryphoribius flavus (Iharos, 1966) & HQ604940 & Bertolani et al. (2014a) \\
\hline $\begin{array}{l}\text { Doryphoribius macrodon Binda, } \\
\text { Pilato \& Dastych, } 1980\end{array}$ & HQ604942 & Bertolani et al. (2014a) \\
\hline $\begin{array}{l}\text { Eremobiotus alicatai (Binda, } \\
\text { 1969) }\end{array}$ & HQ604951 & Bertolani et al. (2014a) \\
\hline $\begin{array}{l}\text { Halobiotus crispae Kristensen, } \\
1982\end{array}$ & $\begin{array}{l}\text { AY582121, } \\
\text { EF620402 }\end{array}$ & $\begin{array}{l}\text { Jørgensen \& } \\
\text { Kristensen (2004), } \\
\text { Møbjerg et al. (2007) }\end{array}$ \\
\hline $\begin{array}{l}\text { Haplomacrobiotus utahensis } \\
\text { Pilato \& Beasley, } 2005\end{array}$ & KT778600 & Cesari et al. (2016) \\
\hline $\begin{array}{l}\text { Hexapodibius micronyx Pilato, } \\
1969\end{array}$ & \multicolumn{2}{|c|}{ HQ604915-6Bertolani et al. (2014a) } \\
\hline Isohypsibius arbiter Binda, 1980 & KT778602 & Cesari et al. (2016) \\
\hline $\begin{array}{l}\text { Isohypsibius dastychi Pilato, } \\
\text { Bertolani \& Binda, } 1982\end{array}$ & HQ604954 & Bertolani et al. (2014a) \\
\hline $\begin{array}{l}\text { Isohypsibius granulifer Thulin, } \\
1928\end{array}$ & KT778603 & Cesari et al. (2016) \\
\hline $\begin{array}{l}\text { Isohypsibius papillifer (Murray, } \\
\text { 1905) }\end{array}$ & EU266925 & Sands et al. (2008) \\
\hline $\begin{array}{l}\text { Isohypsibius prosostomus } \\
\text { prosostomus Thulin, } 1928\end{array}$ & EF620404 & Møbjerg et al. (2007) \\
\hline $\begin{array}{l}\text { Isohypsibius prosostomus } \\
\text { cambrensis (Morgan, 1976) }\end{array}$ & AM500652 & Kiehl et al. (2007) \\
\hline $\begin{array}{l}\text { Pseudobiotus kathmanae Nelson, } \\
\text { Marley \& Bertolani, } 1999\end{array}$ & HQ604957 & Bertolani et al. (2014a) \\
\hline $\begin{array}{l}\text { Pseudobiotus megalonyx } \\
\text { (Thulin, 1928) }\end{array}$ & HQ604959 & Bertolani et al. (2014a) \\
\hline $\begin{array}{l}\text { Thulinius augusti (Murray, 1907) } \\
\text { Thulinius stephaniae (Pilato, 1974) }\end{array}$ & $\begin{array}{l}\text { KF360230 } \\
\text { GQ92570 }\end{array}$ & $\begin{array}{l}\text { Bertolani et al. (2014b) } \\
\text { unpublished }\end{array}$ \\
\hline \multicolumn{3}{|l|}{ Hypsibioidea } \\
\hline $\begin{array}{l}\text { Acutuncus antarcticus } \\
\text { (Richters, 1904) }\end{array}$ & EU266943 & Sands et al. (2008) \\
\hline \multicolumn{3}{|l|}{$\begin{array}{l}\text { Adropion belgicae (Richters, 1911) HQQ } \\
\text { Adropion scoticum (Murray, }\end{array}$} \\
\hline 1905) & HQ604927 & Bertolani et al. (2014a) \\
\hline $\begin{array}{l}\text { Astatumen trinacriae } \\
\text { (Arcidiacono, 1962) }\end{array}$ & $\begin{array}{l}\text { FJ435733, } \\
\text { HQ604922 }\end{array}$ & $\begin{array}{l}\text { Guil \& Giribet (2012), } \\
\text { Bertolani et al. (2014a) }\end{array}$ \\
\hline $\begin{array}{l}\text { Borealibius zetlandicus (Murray, } \\
\text { 1907) }\end{array}$ & HQ604924 & Bertolani et al. (2014a) \\
\hline
\end{tabular}

SYM + I + G. Since RAxML (Stamatakis 2014) allows for only a single model of rate heterogeneity (from the GTR family) in partitioned analyses, using PartitionFinder we additionally tested GTR, GTR + I, GTR + G and GTR + I+G. The best fit-model in this analysis was GTR $+\mathrm{I}+\mathrm{G}$.

\begin{tabular}{|c|c|c|}
\hline Taxon & 18S rRNA & Reference \\
\hline $\begin{array}{l}\text { Calohypsibius ornatus } \\
\text { (Richters, 1900) }\end{array}$ & MH279652 & present study \\
\hline Diphascon higginsi Binda, 1971 & HQ604932 & Bertolani et al. (2014a) \\
\hline $\begin{array}{l}\text { Diphascon pingue (Marcus, } \\
\text { 1936) }\end{array}$ & $\begin{array}{l}\text { FJ435736, } \\
\text { HQ604937 }\end{array}$ & $\begin{array}{l}\text { Guil \& Giribet (2012), } \\
\text { Bertolani et al. (2014a) }\end{array}$ \\
\hline
\end{tabular}

Diphascon puniceum (Jennings, EU266949 Sands et al. (2008) 1976)

Hebesuncus conjungens (Thulin, 1911)

Hebesuncus ryani Dastych \& EU266956 Sands et al. (2008)

Harris, 1994

Hypsibius convergens $\quad$ FJ435726 Guil \& Giribet (2012)

(Urbanowicz, 1925)

Hypsibius klebelsbergi $\quad$ KT901827 Dabert et al. (2015)

Mihelčič, 1959

Hypsibius pallidus Thulin, 1911 HQ604945 Bertolani et al. (2014a)

Hypsibius scabropygus Cuénot, AM500649 Dabert et al. (2014)

1929

Mesocrista revelata Gąsiorek, KU528627 Gąsiorek et al. (2016)

Stec, Morek, Zawierucha,

Kaczmarek, Lachowska-

Cierlik \& Michalczyk, 2016

Mesocrista spitzbergensis

KX347532 Gąsiorek et al. (2016)

(Richters, 1903)

Microhypsibius bertolanii

Kristensen, 1982

Mixibius saracenus (Pilato, 1973) HQ604955 Bertolani et al. (2014a)

Pilatobius nodulosus $\quad$ HQ604934 Bertolani et al. (2014a)

(Ramazzotti, 1957)

Pilatobius patanei (Binda \& $\quad$ HQ604935 Bertolani et al. (2014a) Pilato, 1971)

Pilatobius ramazzottii (Robotti, HQ604939 Bertolani et al. (2014a) 1970)

Platicrista angustata (Murray, HQ604948 Bertolani et al. (2014a) 1905)

Ramazzottius oberhaeuseri AY582122 Jørgensen \& (Doyère, 1840) Kristensen (2004)

Apochela (outgroup)

Milnesium berladnicorum KT951660 Morek et al. (2016b)

Ciobanu, Zawierucha, Moglan

\& Kaczmarek, 2014

Milnesium tardigradum Doyère, MG912554 Morek et al. (2019) 1840

Maximum-likelihood (ML) topologies were constructed using RAxML v8.0.19 (Stamatakis 2014). Strength of support for internal nodes of ML construction was measured using 1000 rapid bootstrap replicates. Bootstrap (BS) support values $\geq 70 \%$ on the final tree were regarded as significant statistical 

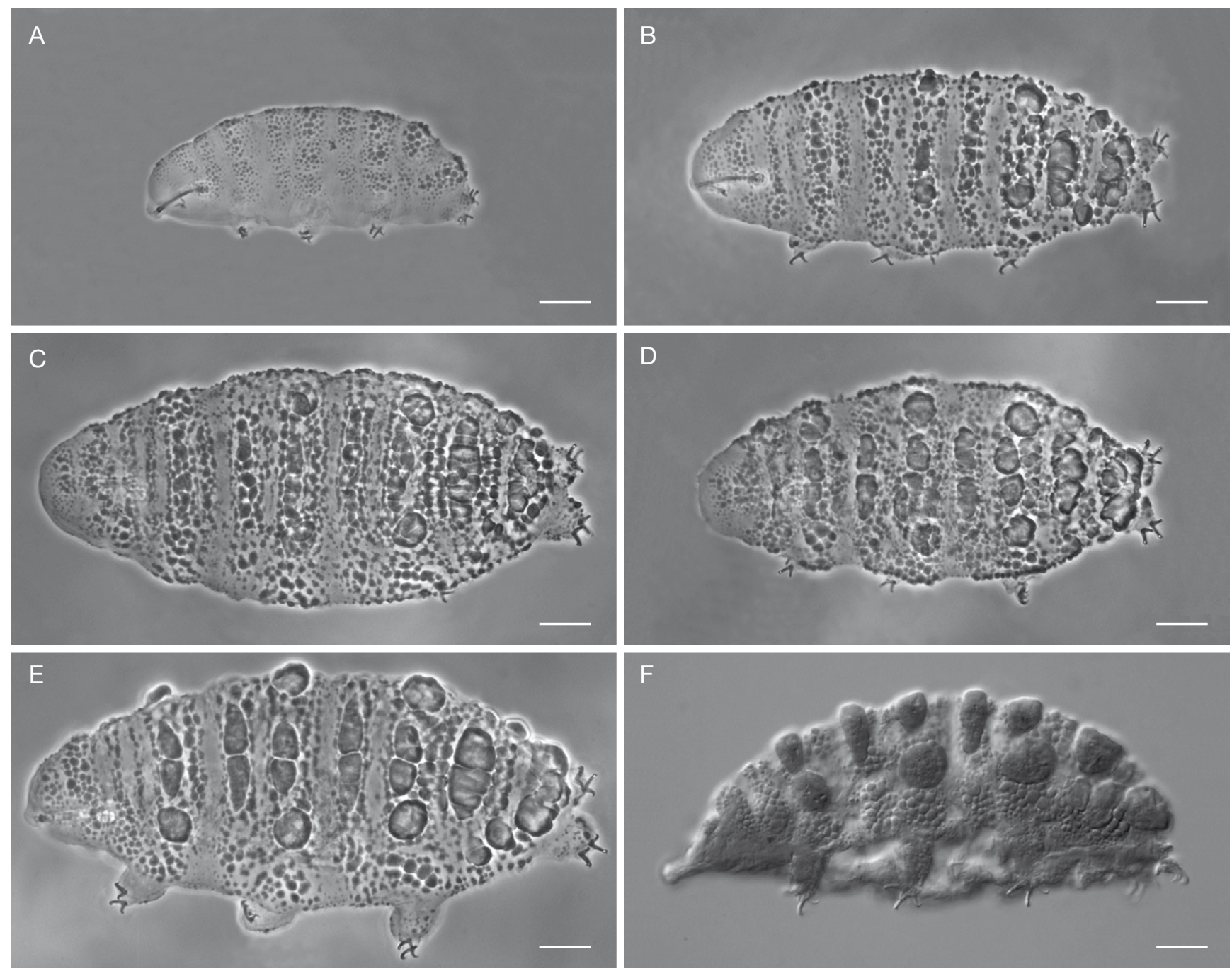

FIG. 1. - Fractonotus verrucosus (Richters, 1900) n. comb., ontogenetic series (Fig. 1F: differential interference contrast [DIC], the remaining photos are phase contrast microscope [PCM]): A, juvenile habitus (lateral view); B, young adult habitus (dorsal view); C-F, old adult habitus, variability in the development of large tubercles (dorsal views); E, adult habitus with the symmetrical arrangement of plaques (Calohypsibius placophorus sensu da Cunha 1943, dorsolateral view); F, adult habitus (a specimen from Borgholm, Öland from the Thulin collection, lateral view, DIC). Scale bars: $20 \mu \mathrm{m}$.

support. Bayesian inference (BI) marginal posterior probabilities were calculated using MrBayes v3.2 (Ronquist \& Huelsenbeck 2003). Random starting trees were used and the analysis was run for ten million generations, sampling the Markov chain every 1000 generations. An average standard deviation of split frequencies of $<0.01$ was used as a guide to ensure the two independent analyses had converged. The program Tracer v1.3 (Rambaut et al. 2014) was then used to ensure Markov chains had reached stationarity and to determine the correct 'burnin' for the analysis which was the first $10 \%$ of generations. A consensus tree was obtained after summarizing the resulting topologies and discarding the 'burn-in'. The BI consensus tree, clades recovered with posterior probability $(\mathrm{PP})$ between 0.95 and 1.00 were considered well supported, those with PP between 0.90 and 0.94 were considered moderately supported and those with lower PP were considered unsupported. All final consensus tree were viewed and visualized by FigTree v.1.4.3 available from http://tree.bio.ed.ac.uk/software/figtree. Uncorrected pairwise distances were calculated using MEGA7 (Kumar et al. 2016).

\section{DATA DEPOSITION}

Morphometric data are provided as Supplementary Materials 1 accessible via the permanent link: http://sciencepress. mnhn.fr/sites/default/files/documents/fr/z2019v41a6_1. xlsx, or via the Digital Object Identifier (DOI): https://doi. org/10.5252/zoosystema2019v41a6_1. DNA sequences were submitted to GenBank (www.ncbi.nlm.nih.gov/genbank). The p-distances are provided as Supplementary Materials 2 accessible via http://sciencepress.mnhn.fr/sites/default/files/ documents/fr/z2019v41a6_2.xlsx, or https://doi.org/10.5252/ zoosystema2019v41a6_2

\section{ABBREVIATIONS}

CU University of Catania, Sicily;

MNHN Muséum national d'Histoire naturelle, Paris;

NHMD Natural History Museum of Denmark, Copenhagen; UAM Department of Animal Taxonomy and Ecology, UJ Institute of Zoology and Biomedical Research, Jagiellonian University, Kraków. 

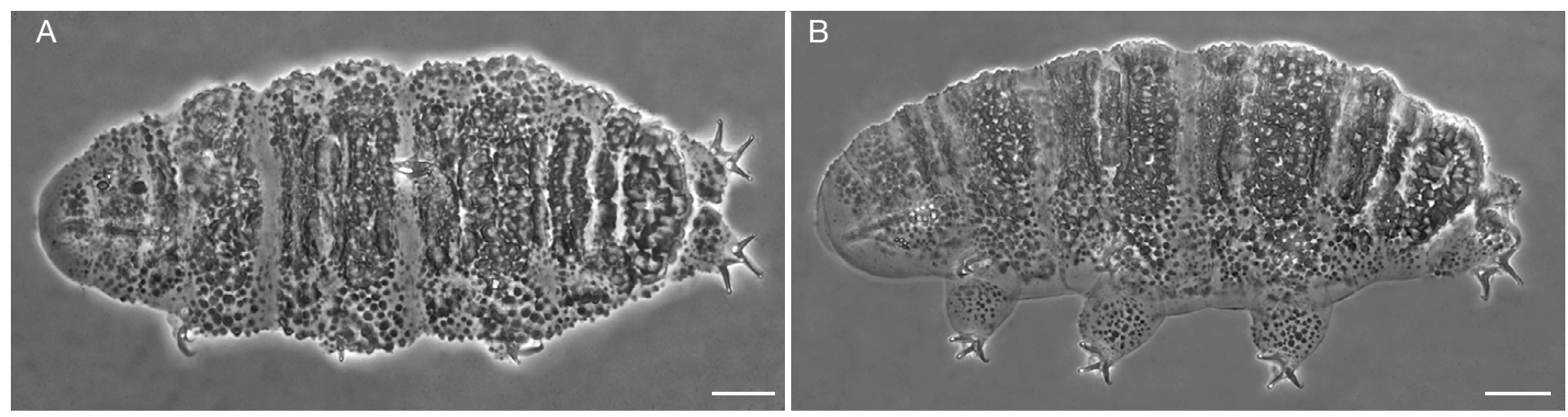

FIG. 2. - Fractonotus gilvus (Biserov, 1986) n. comb., adults showing intraspecific variability in cuticular sculpturing (A, dorsal and B, dorsolateral view, paratypes). Scale bars: $20 \mu \mathrm{m}$.

\section{RESULTS}

Phylum TARDIGRADA Doyère, 1840

Class EUTARDIGRADA Richters, 1926

Order PARACHELA Schuster, Nelson, Grigarick, Christenberry, 1980

Superfamily IsOHYPSIBIOIDEA Sands, McInnes, Marley,

Goodall-Copestake, Convey, Linse, 2008

Family IsOHYPSIBIIDAE Sands, McInnes, Marley, Goodall-

Copestake, Convey, Linse, 2008

\section{Genus Fractonotus Pilato, 1998}

\section{Fractonotus Pilato, 1998: 132.}

AMENDED Diagnosis. - Small isohypsibiid (rarely exceeding $200 \mu \mathrm{m}$, Fig. 1). Cephalic elliptical organs present (Fig. 7A). Dorsum and limbs covered with densely arranged, blunt protuberances. Six peribuccal lobes present (Fig. 6A). Apophyses for the insertion of stylet muscles (AISM) asymmetrical with respect to the frontal plane - the dorsal apophysis subdivided into two portions: the anterior portion in the shape of a slightly convex longitudinal thickening (and the posterior portion as weakly developed blunt hook); the ventral apophysis in the shape of a mild and long ridge (Fig. 9A). Very large pharyngeal apophyses and placoids in the muscle pharynx. Stylet furcae of the Fractonotus-type, i.e. with broad, trapezoid base, thin arms and rounded apices (Figs 8D, 10A). Claws of the modified Isohypsibius-type, with triangular bases and strongly curved claw branches (Fig. 12A, B). Accessory points symmetrical or occasionally asymmetrical. Smooth eggs laid in exuviae.

DIFFERENTIAL DIAGNOSIS. - Fractonotus shares pronounced cuticular sculpturing with some species of six other parachelan genera: Calohypsibius Thulin, 1928, some Ramazzottius Binda \& Pilato, 1986, Hypsibius Ehrenberg, 1848, Pilatobius Bertolani, Guidetti, Marchioro, Altiero, Rebecchi, Cesari, 2014, Doryphoribius Pilato, 1969 and Isohypsibius Thulin, 1928, but it can be readily distinguished from these genera by the morphology of the stylet furcae (square/trapezoid in Fractonotus vs narrower and more rectangular in the latter genera; compare Figs 7B, D; 10A-C). Furthermore, Fractonotus differs from Ramazzottius, Hypsibius and Pilatobius by having Isohypsibius-like claws (claws of the latter genera are of the Hypsibius or of the modified Hypsibius-type). Moreover, the genus differs specifically from:

- Calohypsibius Thulin, 1928 (Hypsibioidea: Calohypsibiidae), by having a different type of cuticular sculpture (roundish or oval tubercles covering the entire dorsum and limbs with smooth dorsal pebble-shaped plaques in Fractonotus, Fig. 5A-D vs multangular or star-like tubercles and occasional spines arranged less densely in Calohypsibius, Fig. 5E, F), different structures surrounding the mouth opening (six soft and large peribuccal lobes in Fractonotus, Fig. 6A vs six small well defined papulae in Calohypsibius, Fig. 6B), a reversed morphology of the dorsal apophysis for the insertion of stylet muscles (an anterior thickening and a tiny posterior hook in Fractonotus, Fig. 7E-G vs an anterior large blunt hook and a slight posterior thickening in Calohypsibius, Fig. 9A, B), and by claw morphology (modified Isohypsibius-type claws with pseudolunulae, triangular bases, and elongated, strongly curved branches with conspicuous accessory points in Fractonotus, Figs 11A-D; 12A, B vs very small, rigid, with the base width equal to the sum of the primary and secondary branch widths, with the vertical septum between the two branches, and without pseudolunulae in Calohypsibius, Figs 11E; 12C, D).

- Doryphoribius Pilato, 1969 (Isohypsibioidea: Isohypsibiidae), by the presence of elliptical organs on the head (absent in Doryphoribius), and by the absence of the ventral lamina on the buccal tube (ventral lamina present in Doryphoribius).

- Isohypsibius Thulin, 1928 (Isohypsibioidea: Isohypsibiidae), by the presence of elliptical organs on the head (absent in Isohypsibius), a different shape of AISM (asymmetrical with respect to the frontal plane in Fractonotus, Fig. 7E vs ridges symmetrical with respect to the frontal plane Isohypsibius, Figs 7H, I; 9A, C), and by the claw morphology (modified Isohypsibius-type claws with triangular bases, especially well-marked on the fourth pair of legs, in Fractonotus vs Isohypsibius-type claws with stalk-like bases in Isohypsibius, Figs $11 \mathrm{H}$, I; $12 \mathrm{E}, \mathrm{F})$.

\section{COMPOSITION AND REMARKS}

Currently only three species, Fractonotus caelatus (the nominal taxon), F. verrucosus n. comb. and F. gilvus n. comb., are assigned to the genus. The three species are placed in the single genus because they share a number of taxonomically important traits: AISM shape, the presence of elliptical cephalic organs, two granular macroplacoids in the pharynx, and the type of cuticular sculpturing. On the other hand, Pilato (1998) described the claws of $F$. caelatus as of the Microhypsibius type, whereas claws in F. verrucosus n. comb. and F. gilvus n. comb. are closer to Isohypsibius type claws. Therefore, given the differences in claw morphology, there is a possibility that $F$ verrucosus n. comb. and F. gilvus n. comb. belong to a new isohypsibioid genus, and are only delusively similar to Fractonotus due to convergent evolution in the remaining traits. Nevertheless, the majority of traits suggest that all three species should be placed in Fractonotus. 

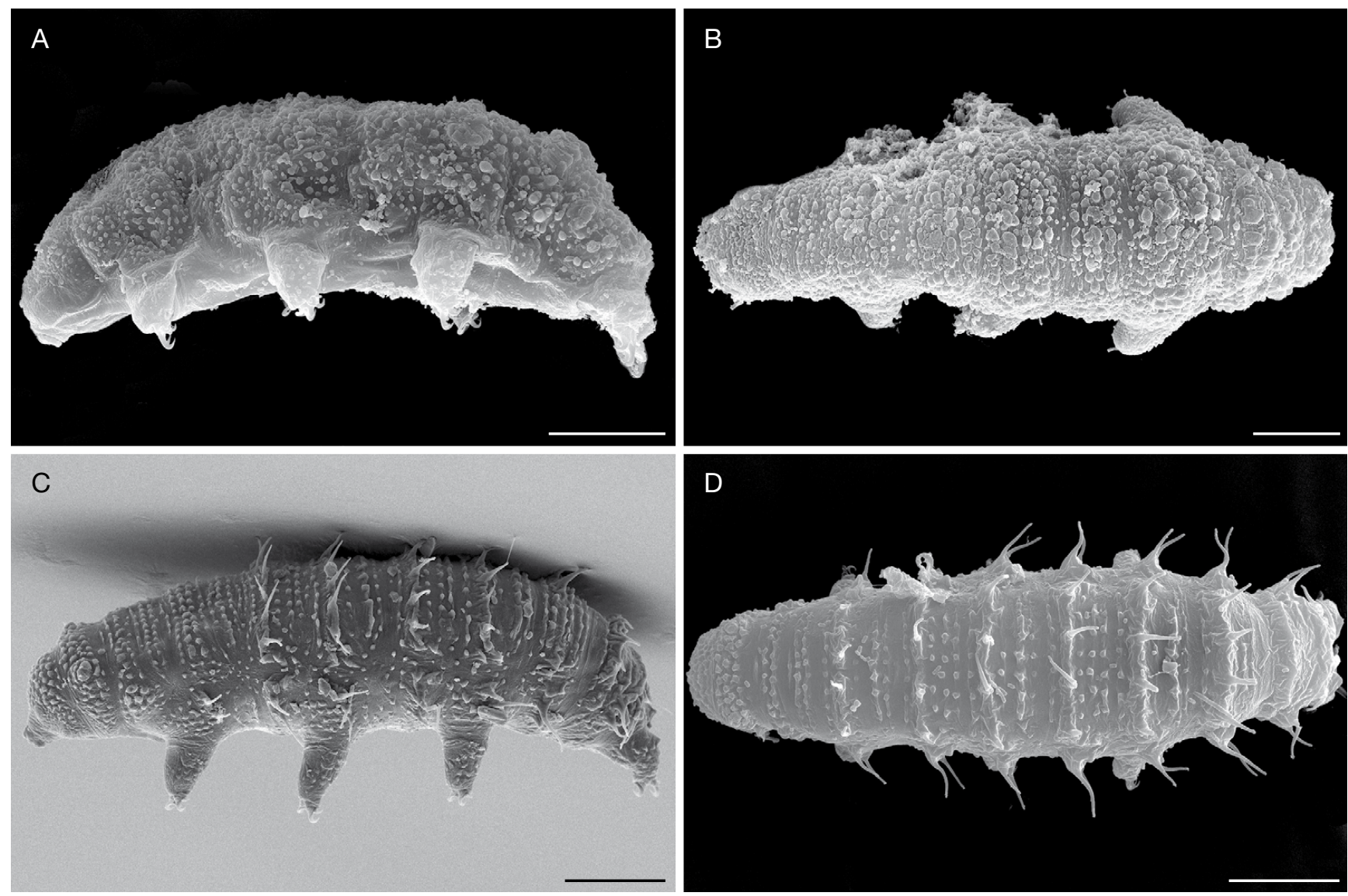

FIG. 3. - Fractonotus verrucosus (Richters, 1900) n. comb., habitus (SEM): A, lateral view; B, dorsal view; Calohypsibius ornatus (Richters, 1900), habitus (SEM): C, lateral view; D, dorsal view. Scale bars: $A, 30 \mu \mathrm{m}$; B-D, $20 \mu \mathrm{m}$.

Biserov (1986) misinterpreted the AISM of F. gilvus n. comb. (Fig. 3 therein) as Isohypsibius-type AISM, but our observations of the type material confirm that the species has the AISM of the Fractonotus-type. However, there are more Isohypsibius and Hypsibius species, that exhibit cuticular sculpturing similar to that of Fractonotus. Thus, they may in fact belong to Fractonotus rather than Isohypsibius or Hypsibius. Nevertheless, we refrained from enacting more transfers, as a careful examination of individuals is needed to confirm whether these species, in addition to cuticular sculpturing, also exhibit other characteristics of Fractonotus.

\section{Fractonotus verrucosus (Richters, 1900)} n. comb.

Macrobiotus ornatus var. verrucosus Richters, 1900: 41 (terra typica: Taunus, Germany).

Macrobiotus scabrosus Murray, 1911: 10 (locus typicus: Clare Island, Ireland).

Hypsibius verrucosus - Thulin 1911: 29 (Kiruna, Lapland, Sweden). - Marcus 1928: 180 (Vannsee, Berlin, Germany). — Cuénot 1932: 77 (the Vosges, France and Switzerland). — da Cunha 1947, 1948: 6, 2 (Serra d'Arga, Serra do Buçaco, Serra da Estrela, Serra da Lousã, Portugal).
Calohypsibius verrucosus - Thulin 1928: 239 (Sweden).

Calohypsibius scabrosus Thulin, 1928: 239 (Sweden).

Hypsibius scabrosus Cuénot, 1932: 77 (the Vosges, France and Switzerland). — da Cunha 1947, 1948: 6, 2 (Serra d'Arga, Serra do Buçaco, Serra da Estrela, Serra da Lousã, Portugal).

Hypsibius (Calohypsibius) verrucosus - Marcus 1936: 285 (Schwarzwald, Germany). - Franceschi 1951-1952: 12 (Val Camonica, Italy). — Mihelčič 1953: 247 (Tirol, Austria). — Fontoura 1981: 18 (Viseu, Arga, Amarante, Portugal).

Hypsibius placophorus da Cunha, 1943: 1 (locus typicus: Cabril do Ceira, Portugal); 1947, 1948: 2, 2 (Serra d'Arga, Serra do Buçaco, Serra da Estrela, Serra da Lousã, Portugal) n. syn.

LOCALITIES. - Scotland. Creag Meagaidh (56 $57^{\circ} 10^{\prime \prime} \mathrm{N}, 4^{\circ} 30^{\prime} 35^{\prime \prime} \mathrm{W}$; $291 \mathrm{~m}$ a.s.l.; collection date: 1.X.2014), lichens from moorland rocks; Scotland, Hebrides, Isle of Lewis, Loch nan Muilne $\left(58^{\circ} 21^{\prime} 08^{\prime \prime} \mathrm{N}\right.$, $6^{\circ} 35^{\prime} 14$ ”W; $27 \mathrm{~m}$ a.s.l.; collection date: 29.VII.2015), moss and lichen mix from stones on the lakeshores; Invermoriston, Loch Ness (57 $12^{\prime} 39^{\prime \prime} \mathrm{N}, 4^{\circ} 35^{\prime} 59^{\prime \prime} \mathrm{W} ; 20$ m a.s.l.; 25.X.2015; Brian Blagden leg.), moss and lichen mix from stones on the lakeshores.

MATERIAL EXAMINED. - 23 individuals, UJ (19 specimens, including one simplex, on slides GB.005.03-12, GB.008.01-3, GB.028.012 and 4 specimens on two SEM stubs); 2 individuals, MNHN (slides GB.005.01-2); 3 individuals, NHMD (slides GB.008.045); 2 individuals, UAM (slides GB.028.03-4); 1 individual, CU (slide GB.028.02). 

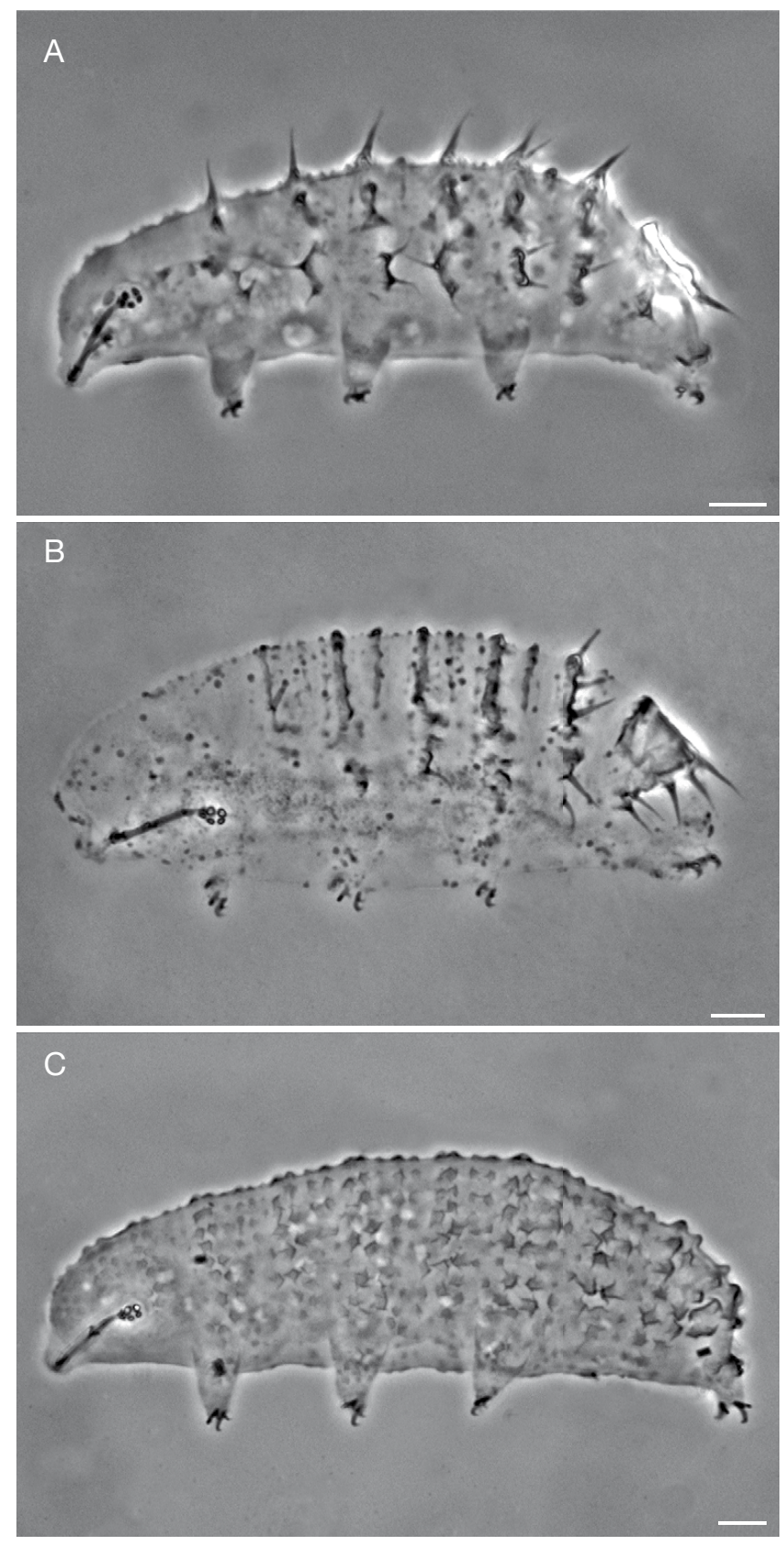

FIG. 4. - Genus Calohypsibius Thulin, 1928 s.s., after exclusion of $F$. verrucosus n. comb. (PCM): A, Calohypsibius ornatus (Richters, 1900); B, Calohypsibius maliki Michalczyk \& Kaczmarek, 2005; C, Calohypsibius schusteri Nelson \& McGlothlin, 1996. Scale bars: $10 \mu \mathrm{m}$.

ETYMOLOGY (NOT PROVIDED IN THE ORIGINAL DESCRIPTION). The name most likely refers to the rugged cuticular surface of the species (from Latin verruca $=$ wart).

DifFERENTIAL DIAGNOSIS. - Fractonotus verrucosus n. comb. can be distinguished from F. caelatus and F. gilvus n. comb. (Fig. 2A, B) by the presence of plaques (absent in the latter species). It also differs from $F$. gilvus n. comb. by shorter, stouter claws (anterior and posterior primary branches 4.1-6.4 $\mu \mathrm{m}[\mathrm{N}=10]$ and 4.3-7.4 $\mu \mathrm{m}$ long [N=18], respectively, in Fractonotus verrucosus n. comb. vs 7.0$13.0 \mu \mathrm{m}[\mathrm{N}=21]$ and $10.5-16.5 \mu \mathrm{m}$ long $[\mathrm{N}=21]$, respectively, in F. gilvus n. comb.; compare Fig. 11A-D).
TABLE 3. - Measurements [in $\mu \mathrm{m}$ ] of selected morphological structures of individuals of Fractonotus verrucosus (Richters, 1900) n. comb. mounted in Hoyer's medium. Abbreviations: N, number of specimens/structures measured; $\boldsymbol{p t}$, the $p t$ index; Range, refers to the smallest and the largest structure among all measured specimens; SD, standard deviation.

\begin{tabular}{|c|c|c|c|c|c|c|}
\hline \multirow[b]{2}{*}{ Character } & \multicolumn{2}{|c|}{ Range } & \multicolumn{3}{|c|}{ Mean } & SD \\
\hline & $\mathbf{N}$ & $\mu \mathrm{m}$ & $p t$ & $\boldsymbol{\mu m}$ & $p t$ & $\mu \mathrm{m} p t$ \\
\hline Body length & 261 & $103-235$ & - & 177 & -3 & $33-$ \\
\hline \multicolumn{7}{|l|}{ Buccal tube } \\
\hline Buccal tube length & 231 & $16.9-27.1$ & - & 23.1 & - & $2.4-$ \\
\hline $\begin{array}{l}\text { Stylet support insertion } \\
\text { point }\end{array}$ & 23 & $9.7-15.8$ & $56.8-62.3$ & 313.6 & 59.2 & 1.41 .5 \\
\hline $\begin{array}{l}\text { Buccal tube external } \\
\text { width }\end{array}$ & 24 & $1.0-1.6$ & $4.8-6.5$ & 1.3 & 5.7 & 0.20 .5 \\
\hline $\begin{array}{l}\text { Buccal tube internal } \\
\text { width }\end{array}$ & 24 & $0.2-0.7$ & $1.2-2.6$ & 0.4 & 1.9 & 0.10 .4 \\
\hline
\end{tabular}

\begin{tabular}{|c|c|c|c|c|}
\hline \multicolumn{5}{|l|}{ Placoid lengths } \\
\hline Macroplacoid 1 & 25 & $1.0-2.7$ & $5.9-11.42 .1$ & $\begin{array}{llll}9.3 & 0.4 & 1.3\end{array}$ \\
\hline Macroplacoid 2 & 25 & $1.3-2.3$ & $6.5-9.51 .8$ & $\begin{array}{lll}8.1 & 0.3 & 0.7\end{array}$ \\
\hline Macroplacoid row & 25 & $3.3-5.3$ & $18.2-21.84 .5$ & 20.00 .51 .0 \\
\hline \multicolumn{5}{|l|}{ Claw 1 lengths } \\
\hline External base & 18 & $2.0-3.9$ & $8.5-14.42 .7$ & 11.70 .61 .8 \\
\hline External primary branch & 18 & $3.5-6.0$ & $16.9-24.04 .8$ & 21.30 .82 .2 \\
\hline $\begin{array}{l}\text { External secondary } \\
\text { branch }\end{array}$ & 13 & $2.7-4.7$ & $12.6-17.53 .4$ & 14.80 .71 .8 \\
\hline Internal base & 17 & $1.5-2.9$ & $7.8-11.62 .3$ & $9.90 .4 \quad 1.0$ \\
\hline Internal primary branch & 12 & $3.0-5.5$ & $17.7-24.24 .5$ & 20.50 .82 .0 \\
\hline $\begin{array}{l}\text { Internal secondary } \\
\text { branch }\end{array}$ & 9 & $2.3-3.9$ & $11.9-15.63 .1$ & 13.60 .51 .1 \\
\hline \multicolumn{5}{|l|}{ Claw 2 lengths } \\
\hline External base & 17 & $2.0-4.4$ & $8.9-16.22 .7$ & 12.00 .72 .4 \\
\hline External primary branch & 17 & $3.2-6.9$ & $16.1-27.15 .0$ & 22.21 .23 .9 \\
\hline $\begin{array}{l}\text { External secondary } \\
\text { branch }\end{array}$ & 11 & $2.4-5.4$ & $11.8-19.93 .8$ & 16.30 .82 .9 \\
\hline Internal base & 10 & $1.5-3.5$ & $7.0-13.32 .5$ & 11.00 .72 .2 \\
\hline Internal primary branch & 8 & $2.7-5.8$ & $19.0-25.14 .9$ & 21.61 .02 .2 \\
\hline $\begin{array}{l}\text { Internal secondary } \\
\text { branch }\end{array}$ & 6 & $3.0-4.3$ & $12.1-17.53 .7$ & 15.20 .51 .8 \\
\hline \multicolumn{5}{|l|}{ Claw 3 lengths } \\
\hline External base & 16 & $1.8-3.7$ & $9.1-16.12 .6$ & 11.90 .62 .0 \\
\hline External primary branch & 14 & $3.8-7.5$ & $19.0-31.65 .3$ & 23.81 .24 .3 \\
\hline $\begin{array}{l}\text { External secondary } \\
\text { branch }\end{array}$ & 14 & $2.4-5.0$ & $11.8-21.13 .5$ & 26.30 .82 .7 \\
\hline Internal base & 14 & $1.7-3.3$ & $8.8-13.42 .3$ & 10.60 .51 .5 \\
\hline Internal primary branch & 11 & $2.8-5.4$ & $16.6-22.44 .5$ & 20.10 .92 .1 \\
\hline $\begin{array}{l}\text { Internal secondary } \\
\text { branch }\end{array}$ & 10 & $2.2-3.9$ & $11.4-16.03 .1$ & 14.40 .71 .5 \\
\hline \multicolumn{5}{|l|}{ Claw 4 lengths } \\
\hline Anterior base & 15 & $1.6-3.7$ & $8.3-13.72 .6$ & 11.30 .61 .8 \\
\hline Anterior primary branch & 10 & $4.1-6.4$ & $19.3-28.45 .4$ & 22.90 .82 .5 \\
\hline $\begin{array}{l}\text { Anterior secondary } \\
\text { branch }\end{array}$ & 6 & $2.3-5.1$ & $15.5-20.44 .2$ & 18.61 .12 .1 \\
\hline Posterior base & 16 & $2.1-4.0$ & $8.6-15.92 .6$ & 11.80 .51 .8 \\
\hline $\begin{array}{l}\text { Posterior primary } \\
\text { branch }\end{array}$ & 18 & $4.3-7.4$ & $20.2-30.75 .7$ & 25.30 .92 .8 \\
\hline $\begin{array}{l}\text { Posterior secondary } \\
\text { branch }\end{array}$ & 8 & $3.1-5.5$ & $16.1-21.94 .3$ & 18.40 .71 .9 \\
\hline
\end{tabular}

\section{INTEGRATIVE DESCRIPTION}

Animals (see Table 3 for measurements)

Body stubby, typically slightly rose in live animals, transparent in mounted specimens. Dorsum strongly sculptured from the first instar, although with substantial ontogenetic quantitative and qualitative variability in this trait (Fig. 1AF). Juveniles with ten transverse bands of numerous tu- 

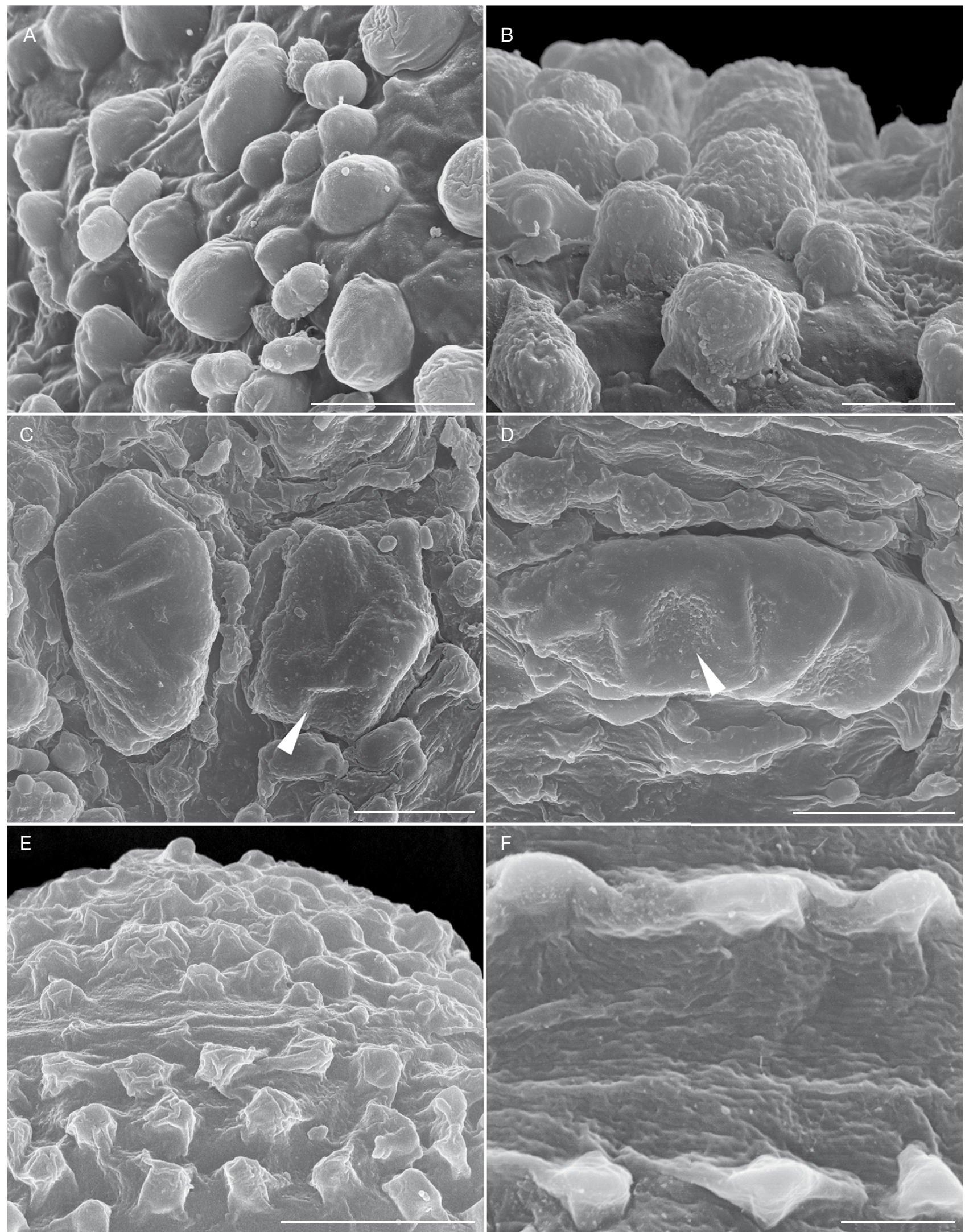

FIG. 5. - A-D, Fractonotus verrucosus (Richters, 1900) n. comb.; E, F, Calohypsibius ornatus (Richters, 1900), cuticle morphology (SEM): Fractonotus-type: A, smooth, obtuse tubercles of the smallest specimens (Calohypsibius scabrosus sensu Murray 1911, Calohypsibius verrucosus sensu da Cunha 1947); B, scabrous tubercles occurring in the caudal part of the smallest specimens and on the whole body of adults; C, D, dorsal plaques of adults (Calohypsibius placophorus sensu da Cunha 1943, Calohypsibius verrucosus sensu Thulin 1911, Marcus 1928 and Cuénot 1932), arrowheads indicate coarse portions of the plaques; Calohypsibius-type: E, irregular, multangular tubercles of the cephalic part; F, rows of tubercles of the trunk in close-up. Scale bars: A, B, F, $2 \mu \mathrm{m} ; \mathrm{C}-\mathrm{E}, 20$ m. 


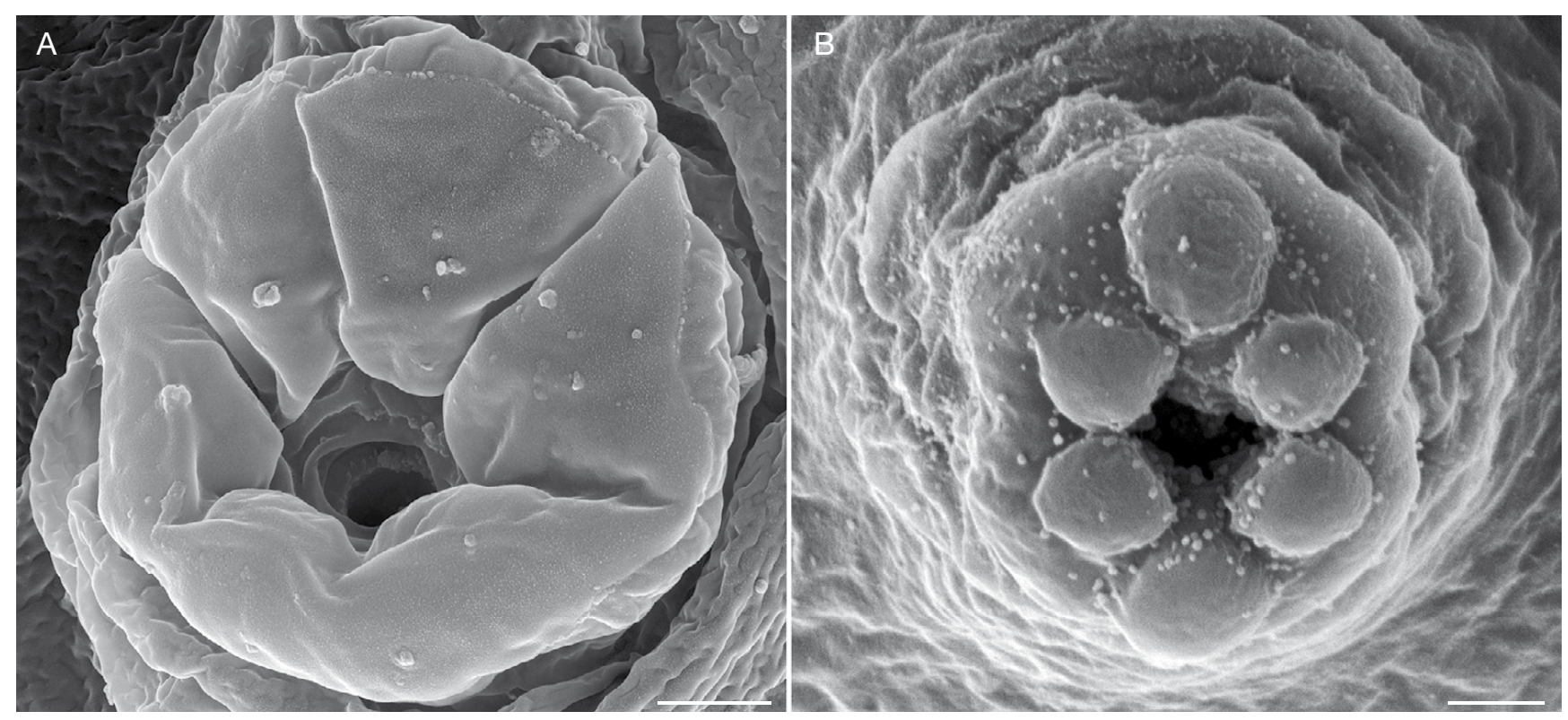

Fig. 6. - Fractonotus verrucosus (Richters, 1900) n. comb. and Calohypsibius ornatus (Richters, 1900), peribuccal structures (SEM): A, Fractonotus verrucosus n. comb., with six peribuccal lobes typical for Isohypsibiidae; B, Calohypsibius ornatus with six small and roundish peribuccal papulae typical for Calohypsibiidae. Scale bars: $1 \mu \mathrm{m}$.

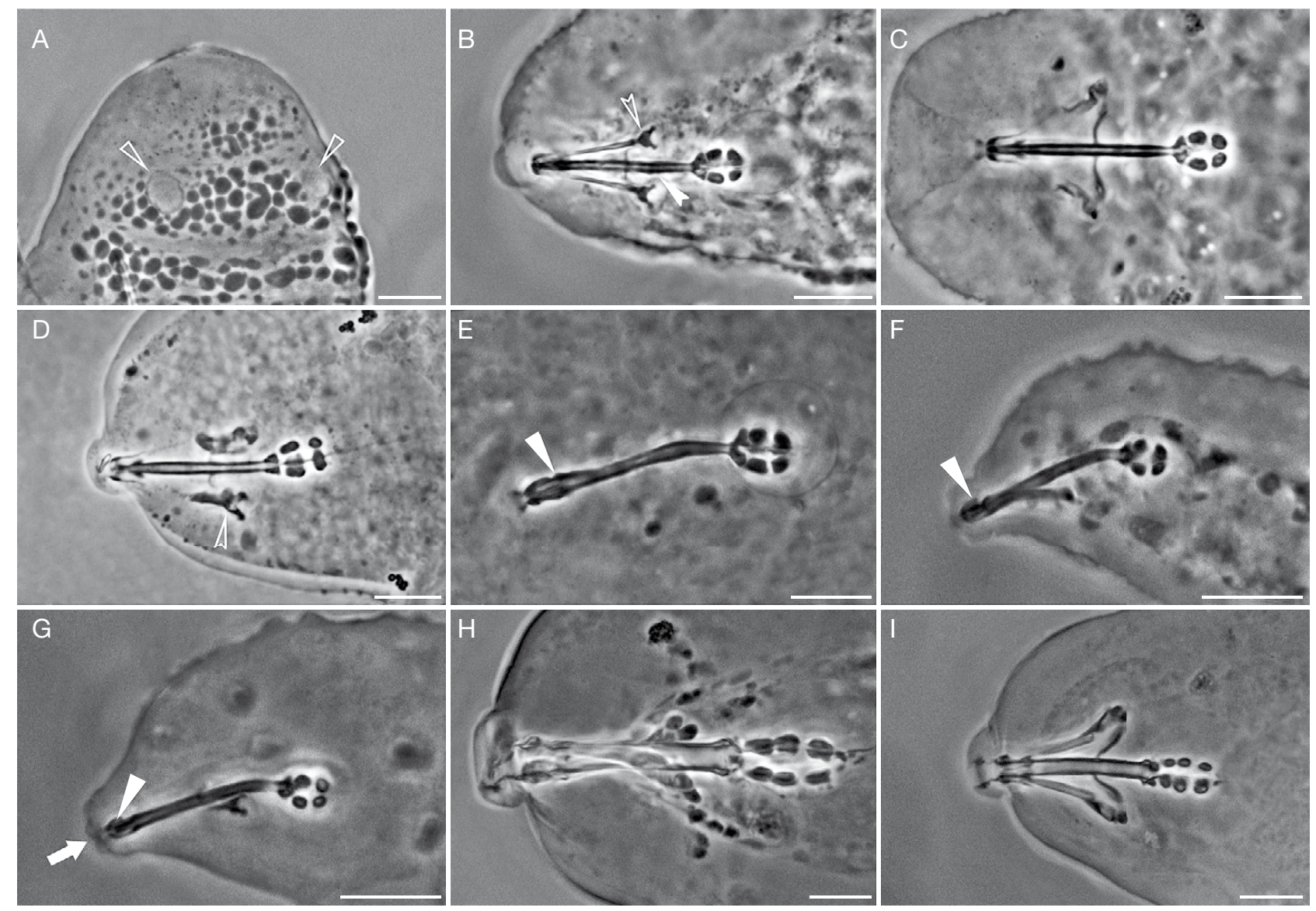

FIG. 7. - A-E, Fractonotus spp., F-G, Calohypsibius spp. and H-I, Isohypsibius spp., elliptical organs and details of the buccal apparatus (PCM): Fractonotus verrucosus (Richters, 1900) n. comb.: A, cephalic region, empty arrowheads indicate elliptical organs; B, dorsal view, incised arrowhead indicates buccal tube thickening, and incised empty arrowhead points to the furca; C, ventral view; Fractonotus gilvus (Biserov, 1986) n. comb.; D, ventral view, incised empty arrowhead points to the furca; Fractonotus verrucosus (Richters, 1900) n. comb.; E, lateral view, arrowhead indicates the posterior portion of dorsal apophysis in the shape of stumpy hook; F, Calohypsibius ornatus (Richters, 1900), lateral view, arrowhead indicates the anterior portion of dorsal apophysis in the shape of stumpy hook; G, Calohypsibius schusteri Nelson \& McGlothlin, 1996, arrowhead indicates the anterior portion of dorsal apophysis in the shape of stumpy hook, and arrow points to the visible peribuccal papulae; H, Isohypsibius prosostomus (Thulin, 1928); I, Isohypsibius coulsoni Kaczmarek, Zawierucha, Smykla, Michalczyk, 2012. Scale bars: 10 m. 

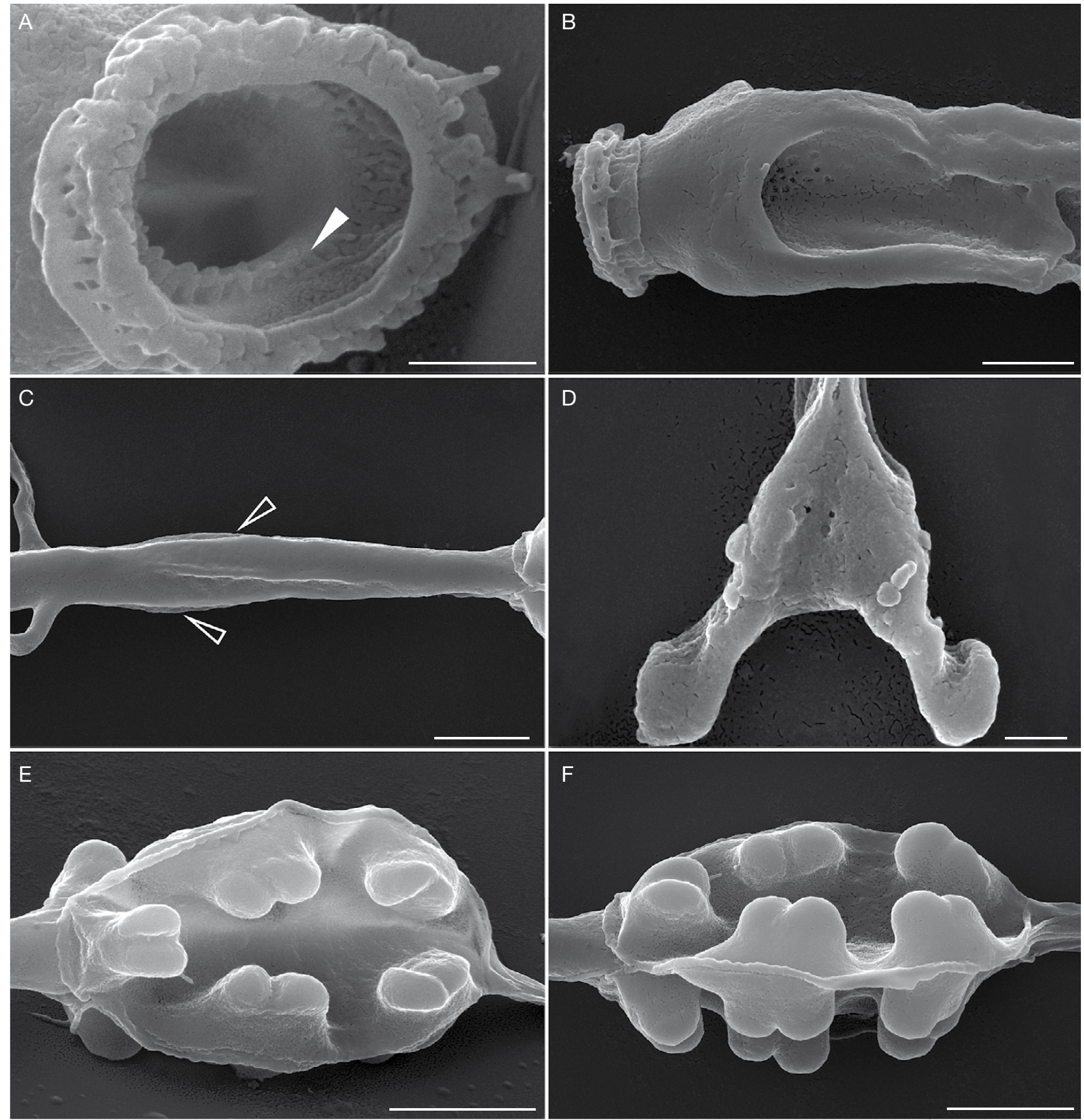

FIG. 8. - Buccal apparatus of Fractonotus verrucosus (Richters, 1900) n. comb. (SEM): A, oral cavity armature, the arrowhead indicates the row of conical teeth; B, the buccal crown and both dorsal and ventral apophyses for insertion of stylet muscles (AISM) in lateral view; $\mathbf{C}$, buccal tube, empty arrowheads indicate lateral thickenings; D, stylet furca; E, pharynx in dorsal view; F, pharynx in lateral view. Scale bars: A, D, $0.5 \mu \mathrm{m} ; \mathrm{B}, 1 \mu \mathrm{m} ; \mathrm{C}, \mathrm{E}, \mathrm{F}, 2 \mu \mathrm{m}$.

bercles that increase in size towards the caudal end of the body, but fully formed plaques never present, legs covered with fine tubercles (Fig. 1A). All ten bands not always easily identifiable under PCM in juveniles. In young adults, plaques present in bands 6-10, with the most prominent plaques in bands 8-10 (Fig. 1B). In older adults, smooth spaces between the transverse bands becoming narrow and sometimes merge into larger areas (Fig. 1C-F). Plaques larger and more numerous than in young adults, and typically developping in bands 4-10, but the most evident plaques present in the caudal part of the body (Fig.1C-F). Tubercles more or less round or oval (Figs 3A, B; 5A, B), gradually increasing in size from juveniles to adults, and becoming scabrous with age (compare Figs 1A-F; 5A, B). Plaques, on the other hand, typically smooth and only sometimes slightly rough (Fig. 5C, D, arrowheads); under stereomicroscope strongly opalescent. Plaques arranged symmetrically in respect to the longitudinal body axis, although deviations 


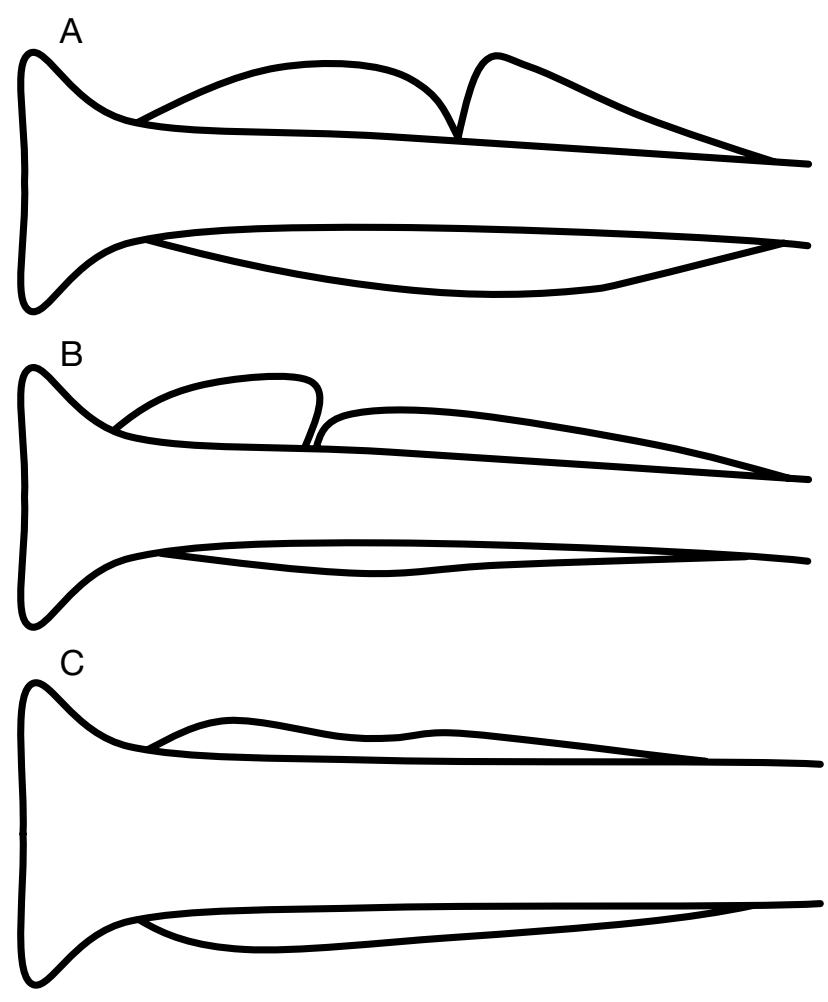

FIG. 9. - Schematic comparison of the AISM (lateral view) in: A, Fractonotus Pilato, 1998; B, Calohypsibius Thulin, 1928; C, Isohypsibius Thulin, 1928.

from symmetry are not rare (Fig. 1C, D). In adults, seven pairs of central plaques and four lateral plaque pairs. Central plaques triangular in shape, with their apices directed laterally and outwards. In rows where only central plaques are present, plaques slimmer and longer than in rows with lateral plaques. Central plaques present in bands aligned with legs I-III as well as in bands between those legs. First three pairs of lateral plaques in line with legs I-III and the last pair of double lateral plaques situated between legs III and IV (Fig. 1E). Plaque configuration VII:4-2-4-2-4-2-6. Cephalic elliptical organs present but not easy to identify, given the rich cuticular sculpturing (Fig. 7A). Eyes absent in live animals.

Buccal apparatus of the Fractonotus-type (Fig. 7B, C, E), i.e. with a long ventral AISM, and the dorsal AISM subdivided into the proximal, weakly developed thickening, and the distal, small blunt hook (Fig. 9A). Mouth opening surrounded by six large and soft peribuccal lobes (visible only under SEM, Fig. 6A). Oral cavity armature, visible only under SEM, consisting of a single row of minute conical teeth located on the ring fold (Fig. 8A). Two distinct porous areas on the lateral sides of the buccal crown are visible in SEM only (Fig. 8B). Stylet furcae of the modified Hypsibius shape, i.e. with very broad and trapezoid bases, thick arms and rounded apices (Figs 7B, 8D, 10A). Buccal tube with slight lateral thickenings posterior to the stylets supports (Figs 7B, C, E; 8C). Round bulbus with large pharyngeal apophyses (almost as large as the placoids), and two granular macroplacoids (Figs 7B, C, E; 8E, F). In PCM, macroplacoids without constrictions, however slight central constrictions in both macroplacoids detectable under SEM (Fig. 8E, F).

Claws of the modified Isohypsibius-type (Figs 11A-C; 12A, B). Specifically, claw bases triangular, especially pronounced in claws IV (Figs 11C, 12B). Claw branches V-shaped, elongated and strongly curved. Apparent accessory points on the primary branches (Figs 11A-C; 12A, B). Weakly developed pseudolunulae present, particularly visible under the internal and anterior claws (Fig. 11A, C). Claw septa and cuticular bars on legs absent.

\section{Eggs}

Roundish and smooth, deposited in exuviae (up to two eggs per exuvia recorded).

\section{MOLECULAR MARKERS}

The sequences for all DNA markers were of a good quality. The sequenced fragments were of the following lengths: 1.727 bp (18S rRNA; MG800855), 819 bp (28S rRNA; MG800856), and 499 bp (ITS-2; MG800857). All markers, including the specimen without cuticular plaques, were represented by single haplotypes. The p-distances between $18 \mathrm{~S}$ haplotypes of all available isohypsibioid species and Fractonotus verrucosus n. comb. ranged from $2.0 \%$ (I. prosostomus Thulin, 1928, EF620404 from Denmark) to 7.1\% (Hexapodibius micronyx Pilato, 1969, HQ604915 from Italy), with an average distance of $5.2 \%$. As our $28 \mathrm{~S}$ rRNA primers obtain a different gene fragment to the one sequenced by previous authors, comparisons of this gene were not possible. Matrices with $\mathrm{p}$-distances are provided in the Supplementary Material 2.

\section{REMARKS}

The vast part of the Richters Collection has been lost, thus the type material (if ever existed) is not available for examination. Moreover, no specimens from Germany were examined in this study, therefore the neotype series is not established. Hence, until the redescription from the terra typica in Germany is available, we propose to consider the description of the Scottish specimens only as the current perception of the species.

\section{PHYLOGENETIC POSITION OF FRACTONOTUS AMONG OTHER ISOHYPSIBIIDAE}

Both Bayesian Inference and Maximum Likelihood methods unreservedly located Fractonotus within Isohypsibioidea (Fig. 13), thus corroborating the phenotypic analysis (see above). The genus Isohypsibius s.s. (i.e. I. prosostomus and its closest relatives) appears paraphyletic with respect to Fractonotus. However, in general, all isohypsibioid lineages clearly remain in polytomy, with only the occasional sound Bayesian posterior probabilities characterising clades with morphologically similar taxa. Therefore, the exact relationships between different isohypsibioid clades remain unsolved. 


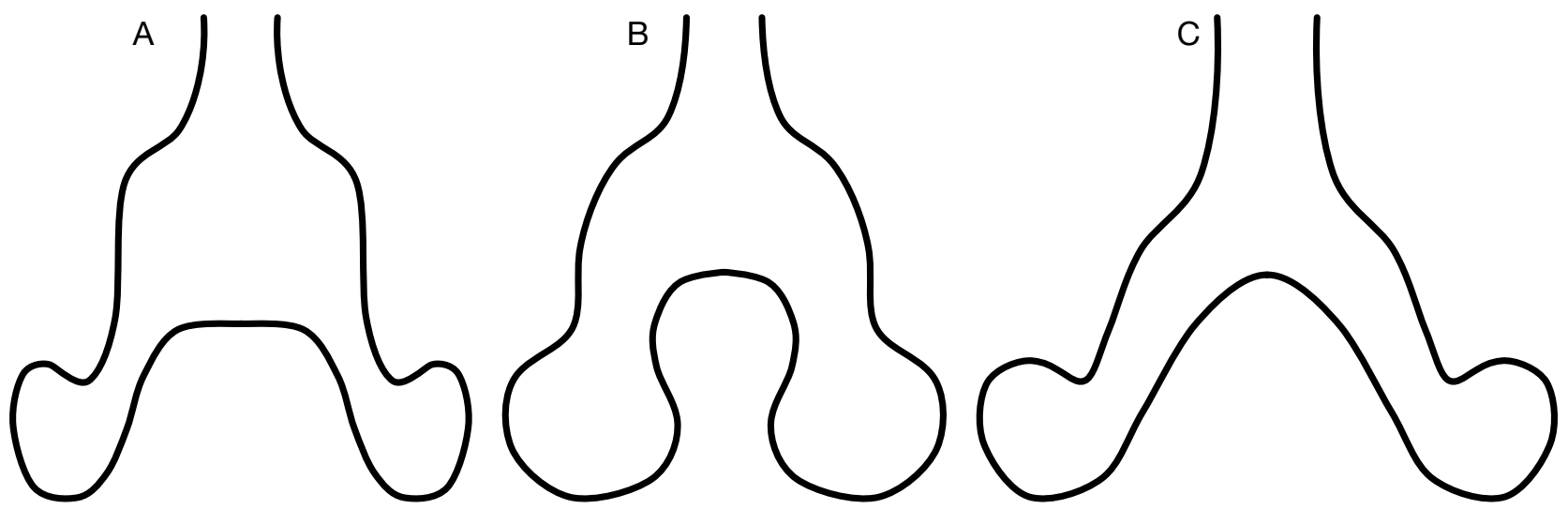

FIG. 10. - Schematic comparison of stylet furcae in: A, Fractonotus Pilato, 1998; B, Calohypsibius Thulin, $1928 ;$ C, Isohypsibius Thulin, 1928.

Fractonotus gilvus (Biserov, 1986) n. comb.

Isohypsibius gilvus Biserov, 1986: 984.

\section{REMARK}

Elliptical organs not always visible due to developed sculpturing in the cephalic portion of the body.

\section{TAXONOMIC ACCOUNT OF THE CALOHYPSIBIIDAE SENSU STRICTO}

Superfamily HyPSIBIOIDEA Pilato, 1969 (emended by Bertolani et al. 2014a)

Family CALOHYPSIBIIDAE Pilato, 1969 (emended by Bertolani et al. 2014a)

EMENDED DIAGNOSIS. - Very small eutardigrades (typically below $150 \mu \mathrm{m}$ ) with elliptical organs on the head. Dorsum covered with irregular, multangular protuberances, and sometimes also with spines (Figs 3C, D; 4; 5E, F). Claws miniaturised, but not reduced, of the Calohypsibius-type, i.e. asymmetrical with respect to the sequence of primary and secondary branches (2-1-2-1), but similar in their size, with bases as large as the sum of the primary and secondary branch widths, but devoid of sutures. Pseudolunulae absent. Accessory points symmetrical (Figs 11E; 12C, D). Six peribuccal papulae present (Fig. 6B). AISM asymmetrical with respect to the frontal plane, with the dorsal apophysis subdivided in two portions of different shape (Fig. 9B). Stylet furcae of the Hypsibius-type (Fig. 10B). Pharyngeal apophyses smaller than the tiny granular macroplacoids. Smooth eggs laid in exuviae.

Composition. - A monotypic family, comprising the genus Calohypsibius.

Genus Calohypsibius Thulin, 1928

Calohypsibius Thulin, 1928: 238.
Diagnosis. - Same as for the family Calohypsibiidae.

ETYMOLOGY (NOT PROVIDED IN THE ORIGINAL DESCRIPTION). -

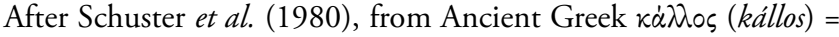
beauty; derivatives calli-, callo- mean beautiful, pretty. Thulin most likely wanted to highlight the cuticular sculpturing, which is exceptionally complex, rich and unusual among Eutardigrada.

\section{COMPOSITION AND REMARKS}

Currently only three species, namely $C$. maliki Michalczyk \& Kaczmarek, 2005 (Fig. 4B), C. ornatus (Richters, 1900) (type species; Figs 3C, D, 4A), and C. schusteri Nelson \& McGlothlin, 1996 (Fig. 4C), are ascribed to the family. Nevertheless, Bartoš (1940) already described the remarkable variability within European records of the ornatus complex, which raises justifiable concerns as to whether $C$. ornatus encompasses only a single species. Further, as suggested by Pilato (1998), it is very likely that the genus comprises many more species than currently recognised. However, a systematic integrative study based on extensive sampling is needed to verify this hypothesis.

\section{TAXONOMIC ACCOUNT}

OF THE MICROHYPSIBIIDAE SENSU STRICTO

Superfamily HyPSIBIOIDEA Pilato, 1969

(emended by Bertolani et al. 2014a)

Family MicrohyPSIBIIDAE Pilato, 1998

EMENDED DIAGNOSIS. - Very small eutardigrades (typically below $150 \mu \mathrm{m}$ in length) without elliptical organs on the head. Cuticle smooth. Claws minute and asymmetrical with respect to the sequence of primary and secondary branches (2-1-2-1), with thin bases continuous with the primary branches. External and internal, and anterior and posterior claws different in shape but similar in size. Pseudolunulae absent. Accessory points symmetrical (Fig. 11G). Peribuccal papulae not visible under PCM. AISM 


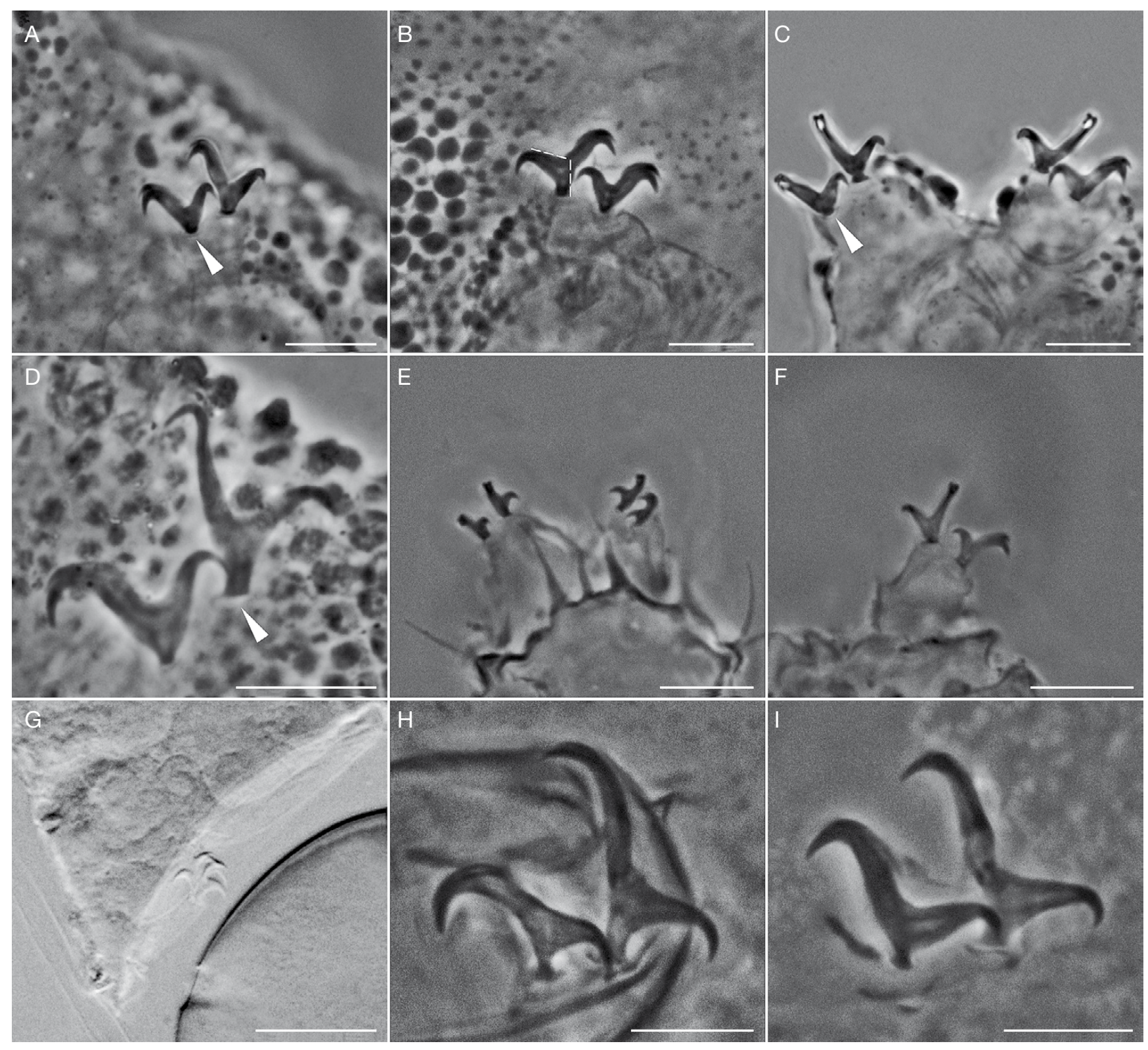

FIG. 11. - Comparison of Fractonotus-type (A-D, F), Calohypsibius-type (E), Microhypsibius-type (G), and /sohypsibius-type (H, I) claws (all but Fig. 11F PCM): Fractonotus verrucosus (Richters, 1900) n. comb.: A, claws I, arrowhead indicates weakly developed pseudolunula; B, claws II, interrupted line designates isohypsibioid claw curvature; C, claws IV, arrowhead indicates weakly developed pseudolunula; Fractonotus gilvus (Biserov, 1986) n. comb.; D, claws III, arrowhead indicates weakly developed pseudolunula; Calohypsibius ornatus (Richters, 1900); E, claws IV; Fractonotus caelatus (Marcus, 1928); F, claws IV; Microhypsibius truncatus Thulin, 1928; G, claws III (DIC); Isohypsibius prosostomus (Thulin, 1928); H, claws II; Isohypsibius coulsoni Kaczmarek, Zawierucha, Smykla \& Michalczyk, 2012; I, claws II. Scale bars: $10 \mu \mathrm{m}$.

asymmetrical with respect to the frontal plane, with the dorsal apophysis subdivided in two portions of different shapes (Fig. 9A). Stylet furcae of the Hypsibius-type. Pharyngeal apophyses similar in size to macroplacoids. Smooth eggs laid in exuviae.

Composition. - A monotypic family, comprising the genus Microhypsibius.

Genus Microhypsibius Thulin, 1928

DiAGNOSIs. - Same as for the family Microhypsibiidae.
ETYMOLOGY (NOT PROVIDED IN THE ORIGINAL DESCRIPTION). The name was most likely chosen to underline the minute size of the family members.

Composition. - Microhypsibius bertolanii Kristensen, 1982, M. japonicus Ito, 1991, M. minimus Kristensen, 1982, M. truncatus Thulin, 1928 (type species).

REMARKS

See Kristensen (1982) for the most current depiction of the genus Microhypsibius. 

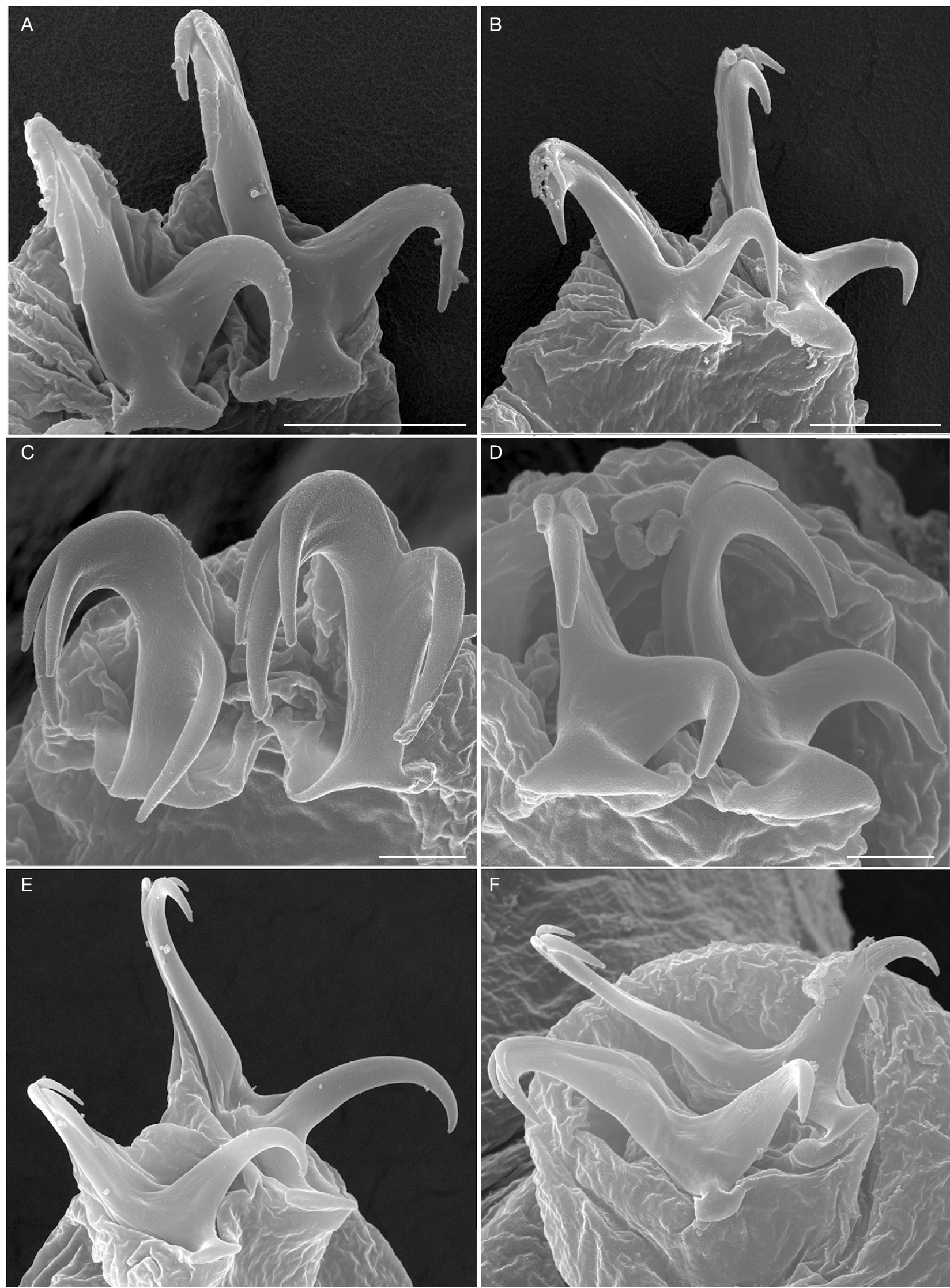

FIG. 12. - A-B, Fractonotus verrucosus (Richters, 1900) n. comb.; C-D, Calohypsibius ornatus (Richters, 1900); E-F, Isohypsibius spp., claws (SEM): Fractonotustype: A, claws III; B, claws IV; Calohypsibius-type; C, claws II; D, claws IV; Isohypsibius-type; E, Isohypsibius prosostomus (Thulin, 1928), claws I; F, Isohypsibius coulsoni Kaczmarek, Zawierucha, Smykla \& Michalczyk, 2012, claws II. Scale bars: A, B, $3 \mu \mathrm{m} ; \mathrm{C}, \mathrm{D}, 1 \mu \mathrm{m} ; \mathrm{E}, \mathrm{F}, 4 \mu \mathrm{m}$. 


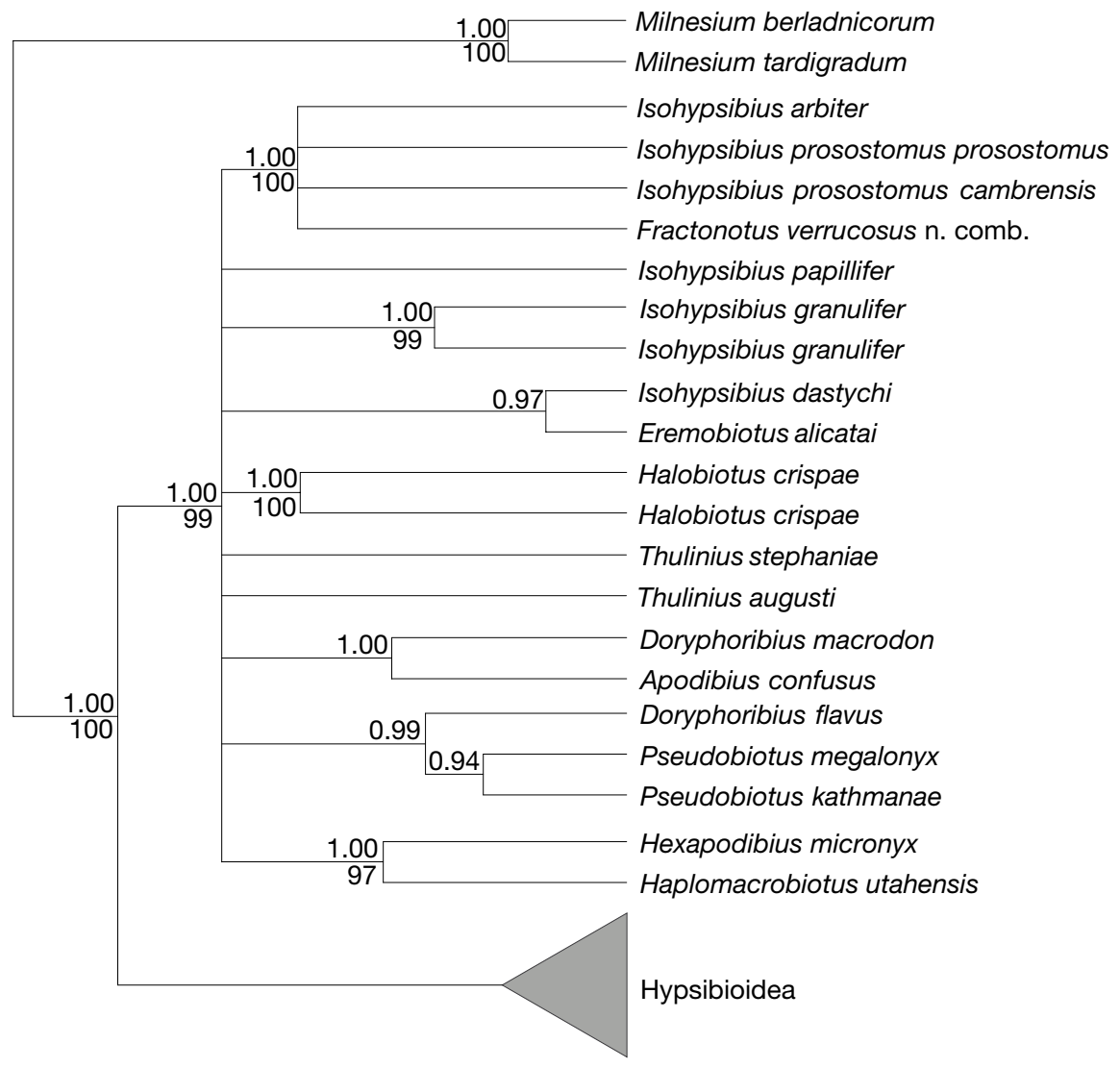

FIG. 13. - The phylogenetic position of Fractonotus verrucosus (Richters, 1900) n. comb. on the Bayesian Inference and Maximum Likelihood cladogram constructed from currently available $18 \mathrm{~S}$ rRNA sequences for Isohypsibioidea and Hypsibioidea, with a Milnesium spp. sequence as the outgroup (see also Table 2). Values above branches indicate posterior probability values (BI), whereas values under branches show bootstrap values (ML). Branches with support below 0.9 in $\mathrm{BI}(70 \%$ in $\mathrm{ML})$ were collapsed.

\section{DISCUSSION}

\section{COMPARISON WITH EARLIER DESCRIPTIONS}

\section{OF THE VERRUCOSUS COMPLEX}

The descriptions of Macrobiotus verrucosus by Richters (1900), M. scabrosus by Murray (1911), and Hypsibius placophorus by da Cunha (1943) are brief and affected by opposing opinions on what represents intra- and inter-specific variation. Our molecular analyses confirmed, however, that both corrugated and rugose forms with plaques (i.e. the first instar and an adult instar) belong to the same species, which is in agreement with the prediction by Cuénot (1932), who explicitly expressed doubts about whether Calohypsibius verrucosus and C. scabrosus truly represent separate species as sometimes they were distinguished only by the presence/absence of eyes. Of the earlier researchers, the most significant observations were made by Murray (1911) who pointed out conspicuously large pharyngeal apophyses and claws with V-shaped branches, which now can be considered as autapomorphies of Fractonotus.

It must be noted that the taxonomic obscurities which accrued around the verrucosus complex very likely resulted from very small sample sizes. With few individuals, some populations may have comprised only juvenile forms (F. verrucosus n. comb.), and other of only young or older adults
(C. scabrosus and C. placophorus n. syn., respectively). This explicitly demonstrates how important in tardigrade systematics are: 1) a proper sample size; and 2) the examination of both juveniles and adults when describing new species (e.g. see Stec et al. 2016 and Morek et al. 2016b, respectively).

All above mentioned names are now designated as younger synonyms of $F$. verrucosus (Richters, 1900) n. comb. The original description of this species is limited, and the taxon is in urgent need of redescription, as is F caelatus. Moreover, given that the latter species received a more recent description based on specimens found on different continents (Pilato et al. 1989), it is likely that it may comprise multiple taxonomic identities. Furthermore, as noted in the remarks above, the monophyly of Fractonotus is uncertain, as F. caelatus exhibits slightly different claw morphology from $F$. verrucosus n. comb. and F. gilvus n. comb. Therefore, the composition and definition of the genus is likely to be amended in the future, when DNA sequences for $F$ caelatus and $F$ gilvus n. comb. are available.

\section{FRACTONOTUS VS ISOHYPSIBIUS SENSU LATO}

The obtained Bayesian and Maximum Likelihood phylogenetic trees are generally very similar to the one presented by Cesari et al. (2016). However, the genus Isohypsibius s.s. should contain the nominal species, I. prosostomus, and its 
closest congeners, whereas in the present study this hypothetical clade is paraphyletic with respect to Fractonotus (Fig. 13). On the other hand, this topology may be an artefact resulting from the generally high conservatism of $18 \mathrm{~S}$ and $28 \mathrm{~S}$ rRNA markers, which does not allow for confident separation of the two genera due to their close affinity in respect to other isohypsibiids (see Suppl. Mat.2). Nevertheless, molecular affinity of Isohypsibius s.s. and Fractonotus is congruent with the modified Isohypsibius-type claws in the latter genus, and suggests that claw morphology in the systematics of the isohypsibioid lineage ought not to be neglected.

In the available limited isohypsibiid molecular dataset, F. verrucosus n. comb. clusters with $I$. prosostomus cambrensis Morgan, 1976, a species exhibiting distinctly granulated cuticle. This indicates that evidently sculptured cuticle may be an important supraspecific character, and it may have broad phylogenetic implications. Currently, Isohypsibius is the most speciose, 'super-polyphyletic' eutardigrade genus (Bertolani et al. 2014a, Cesari et al. 2016). Given that some of the species currently assigned to Isohypsibius and Hypsibius s.l. exhibit a high resemblance to Fractonotus in cuticle and claw morphology, they may eventually turn out to be more related to Fractonotus than to I. prosostomus and its immediate kin, thus representing convergently evolving lineages.

\section{Acknowledgements}

Roberto Bertolani, Roberto Guidetti (University of Modena and Reggio Emilia, Modena) and Roberta Salmaso (The Civic Natural History Museum of Verona, Italy) are acknowledged for making the Biserov collection available to us and for sending us images of the Isohypsibius gilvus holotype. PG is grateful to Reinhardt Møbjerg Kristensen (Natural History Museum of Denmark in Copenhagen) for his help in obtaining valuable DIC microphotographs of tardigrades deposited in the Zoological Museum in Copenhagen. We are grateful to Krzysztof Zawierucha (Adam Mickiewicz University, Poznań, Poland) for sending the samples with I. coulsoni and for critical reading of the manuscript. We would also like to thank Reinhardt M. Kristensen, Izabela Poprawa (University of Silesia in Katowice, Poland) and Łukasz Kaczmarek (Adam Mickiewicz University, Poznań, Poland) for their comments on the manuscript. The authors are also thankful to Shona Morrison (SEPA, Scotland) and Paulina Kosztyła (Jagiellonian University, Poland) for sampling in Outer Hebrides and France, respectively. All material has been collected under appropriate collection permits and approved ethics guidelines. Specimens from the Thulin Collection were accessed and photographed via funding from the European Commission's programme "Transnational Access to Major Research Infrastructures" via SYNTHESYS (grant no. DK-TAF-1163 to ŁM). The study was supported by the Jagiellonian University subsidy no. K/ZDS/006320. The reviewers and the editor helped to improve the manuscript. Giovanni Pilato (University of Catania, Italy) kindly provided us with PCM photomicrographs and his opinion on the morphology of F. caelatus.

\section{REFERENCES}

BARTOŠ E. 1940. - Über die Variation der Art Hypsibius ornatus Richt. (Tardigrada). Zoologische Jahrbücher abteilung für Systematik Ökologie und Geographie der Tiere 73: 369-384.

BEASLEy C. W., KACZMAREK Ł. \& MichalCZYK Ł. 2008. — Doryphoribius mexicanus, a new species of Tardigrada (Eutardigrada: Hypsibiidae) from Mexico (North America). Proceedings of the Biological Society of Washington 121: 34-40. https://doi. org/10.2988/07-30.1

Bertolani R., Guidetti R., Marchioro T., Altiero T., RebecCHI L. \& CESARI M. 2014a. - Phylogeny of Eutardigrada: New molecular data and their morphological support lead to the identification of new evolutionary lineages. Molecular Phylogenetics and Evolution 76: 110-126. https://doi.org/10.1016/j. ympev.2014.03.006

Bertolani R., Bartels P. J., Guidetti R., Cesari M. \& Nelson D. R. 2014b. - Aquatic tardigrades in the Great Smoky Mountains National Park, North Carolina and Tennessee, U.S.A., with the description of a new species of Thulinius (Tardigrada, Isohypsibiidae). Zootaxa 3764 (5): 524-536. https://doi.org/10.11646/ zootaxa.3764.5.2

BisEROV V. I. 1986. - Terrestrial water bears from the North Caucasus. 2. Eutardigrada. Zoologicheskii Zhurnal 65 (7): 981-993.

Campbell L. I., Rota-Stabelli O., Edgecombe G. D., MarChioro T., Longhorn S. J., Telford M. J., Philippe H., Rebecchi L., Peterson K. J. \& PisAni D. 2011. - MicroRNAs and phylogenomics resolve the relationships of Tardigrada and suggest that velvet worms are the sister group of Arthropoda. PNAS 108 (38): 15920-15924. https://doi.org/10.1073/pnas. 1105499108

CASQuet J., Thebaud C. \& Gillespie R. G. 2012. — Chelex without boiling, a rapid and easy technique to obtain stable amplifiable DNA from small amounts of ethanol-stored spiders. Molecular Ecology Resources 12: 136-141. https://doi.org/10.1111/j.17550998.2011.03073.x

Cesari M., Vecchi M., Palmer A., Bertolani R., Pilato G., ReBECCHI L. \& GuideTti R. 2016. - What if the claws are reduced? Morphological and molecular phylogenetic relationships of the genus Haplomacrobiotus May, 1948 (Eutardigrada, Parachela). Zoological Journal of the Linnean Society 178: 819-827. https://doi.org/10.1111/zoj.12424

CuÉNOT L. 1932. - Tardigrades, in LeChEvalier P. (ed.). Faune de France 24: 1-96.

CUNHA A. X. DA 1943. - Un Tardigrade nouveau de Portugal: Hypsibius placophorus sp. n. Memórias e estudos do Museu zoológico da Universidade de Coimbra 155: 1-5.

CunHa A. X. 1947 da . - Tardigrados da Fauna Portuguesa III. Memórias e estudos do Museu zoológico da Universidade de Coimbra 177: 1-9.

CunHA A. X. DA 1948. - Tardigrados da Fauna Portuguesa IV. Memórias e estudos do Museu zoológico da Universidade de Coimbra 188: 1-8.

Dabert M., Dastych H., Hohberg K. \& Dabert J. 2014. — Phylogenetic position of the enigmatic clawless eutardigrade genus Apodibius Dastych, 1983 (Tardigrada), based on 18S and 28S rRNA sequence data from its type species $A$. confusus. Molecular Phylogenetics and Evolution 70: 70-75. https://doi.org/10.1016/j. ympev.2013.09.012

DABerT M., DAstych H. \& DABert J. 2015. - Molecular data support the dispersal ability of the glacier tardigrade Hypsibius klebelsbergi Mihelčič, 1959 across the environmental barrier (Tardigrada). Entomologische Mitteilungen aus dem Zoologischen Museum Hamburg 17 (194): 233-240.

Degma P. \& GUIDETTI R. 2007. - Notes to the current checklist of Tardigrada. Zootaxa 1579: 41-53.

Degma P., Bertolani R. \& GuidetTi R. 2009-2017. — Actual checklist of Tardigrada species. www.tardigrada.modena.unimo. it $/$ miscellanea/Actual $\% 20$ checklist $\% 20$ of $\% 20$ Tardigrada.pdf, p. 46. Accessed 25.12.2017. 
Doyère M. L. 1840. — Mémorie sur les Tardigrades. Annales des Sciences naturelles, Paris, Series 2 14: 269-362.

EibYE-JACOBSEN J. 2001. - A new method for making SEM preparations of the tardigrade buccopharyngeal apparatus. Zoologischer Anzeiger 240: 309-319. https://doi.org/10.1078/0044-5231-00038

FonTOURA A. P. 1981. - Contribution pour l'étude des tardigrades terrestres du Portugal, avec la description d'une nouvelle espèce du genre Macrobiotus. Publicaçóes do Instituto de Zoologia 'Dr Augusto Nobre', Faculdade de Ciências do Porto 160: 1-24.

FRANCESCHI T. 1951-1952. - Contributo alla conoscenza dei Tardigradi d'Italia. Bollettino dei Musei e degli Istituti Biologici dell'Università di Genova 24 (149): 5-15.

Gąsiorek P., SteC D., MoreK W., ZaWierucha K., KaCZMareK Ł. LACHOWSKA-CIERLIK D. \& MiCHALCZYK Ł. 2016. — An integrative revision of Mesocrista Pilato, 1987 (Tardigrada: Eutardigrada: Hypsibiidae). Journal of Natural History 50 (45-46): 2803-2828. https://doi.org/10.1080/00222933.2016.1234654

GĄSIOREK P., ZaWIERUCHA K., STEC D. \& MichalCZYK Ł. 2017. Integrative redescription of a common Arctic water bear Pilatobius recamieri (Richters, 1911). Polar Biology 40: 2239-2252. https:// doi.org/10.1007/s00300-017-2137-9

GąSiorek P., Stec D., ZaWierucha K., Kristensen R. M. \& MiCHALCZYK Ł. 2018. - Revision of Testechiniscus Kristensen, 1987 (Heterotardigrada: Echiniscidae) refutes the polar-temperate distribution of the genus. Zootaxa 4472 (2): 261-297. https:// doi.org/10.11646/zootaxa.4472.2.3

Guil N. \& GiribeT G. 2012. - A comprehensive molecular phylogeny of tardigrades - adding genes and taxa to a poorly resolved phylum-level phylogeny. Cladistics 28: 21-49. https:// doi.org/10.1111/j.1096-0031.2011.00364.x

Guil N., Machordom A. \& GuidetTi R. 2013. - High level of phenotypic homoplasy amongst eutardigrades (Tardigrada) based on morphological and total evidence phylogenetic analyses. Zoological Journal of the Linnean Society 169: 1-26. https://doi. org/10.1111/zoj.12046

HALL T. A. 1999. - BioEdit: a user-friendly biological sequence alignment editor and analysis program for Windows 95/98/NT. Nucleic Acids Symposium Series 41: 95-98.

JøRGENSEN A. \& KRISTENSEN R. M. 2004. - Molecular phylogeny of Tardigrada - investigation of the monophyly of Heterotardigrada. Molecular Phylogenetics and Evolution 32: 666-670. https:// doi.org/10.1016/j.ympev.2004.04.017

KacZMareK Ł., ZaWierucha K., SmyKla J. \& MichalczyK $Ł$. 2012. - Tardigrada of the Revdalen (Spitsbergen) with the descriptions of two new species: Bryodelphax parvuspolaris (Heterotardigrada) and Isohypsibius coulsoni (Eutardigrada). Polar Biology 35: 1013-1026. https://doi.org/10.1007/s00300-011-1149-0

KATOH K. \& TOH H. 2008. - Recent developments in the MAFFT multiple sequence alignment program. Brief Bioinformatics 9 (4): 286-298. https://doi.org/10.1093/bib/bbn013

KaTOH K., MisaWa K., Kuma K. \& Miyata T. 2002. — MAFFT: a novel method for rapid multiple sequence alignment based on fast Fourier transform. Nucleic Acids Research 30 (14): 3059-3066.

Kiehl E., Dastych H., D'Haese J. \& Greven H. 2007. - The $18 \mathrm{~S}$ rDNA sequences support polyphyly of Hypsibiidae (Eutardigrada). Journal of Limnology: Proceedings of the Tenth International Symposium on Tardigrada 66(S1): 21-25. https://doi.org/10.4081/ jlimnol.2007.s1.21

KRISTENSEN R. M. 1982. - New aberrant eutardigrades from homothermic springs on Disko Island, West Greenland. In: Nelson, D. R. (ed.), Proceedings of the Third International Symposium on the Tardigrada, 1980, 203-220.

Kumar S., STECHER G. \& TAMURA K. 2016. — MEGA7: Molecular Evolutionary Genetics Analysis version 7.0 for bigger datasets. Molecular Biology and Evolution 33 (7): 1870-1874. https://doi. org $/ 10.1093 / \mathrm{molbev} / \mathrm{msw} 054$

Lanfear R., Frandsen P. B., Wright A. M., Senfeld T. \& CalСОТT B. 2016. - PartitionFinder 2: new methods for selecting partitioned models of evolution formolecular and morphological phylogenetic analyses. Molecular Biology and Evolution 34 (3): 772-773. https://doi.org/10.1093/molbev/msw260

MarCus E. 1928. — Spinnentiere oder Arachnoidea. IV: Bärtierchen (Tardigrada). Tierwelt Deutschlands und der angrenzenden Meeresteile Jena 12: 1-230.

Marcus E. 1936. - Tardigrada. Das Tierreich, de Gruyter \& Co., Berlin and Leipzig 66: 1-340.

MAY R.-M. 1948. - Nouveau genre et espèce de tardigrade du Mexique: Haplomacrobiotus hermosillensis. Bulletin de la Société Zoologique de France 73: 95-97.

MichalcZYK Ł. \& KACZMAREK Ł. 2003. - Water Bears (Tardigrada) of the Bieszczady Mountains (Poland, West Carpathians). Zootaxa 242: 1-24.

MichALCZYK $Ł$. \& KACZMAREK $Ł . ~ 2005$. - The first record of the genus Calohypsibius Thulin, 1928 (Eutardigrada: Calohypsibiidae) from Chile (South America) with a description of a new species Calohypsibius maliki. New Zealand Journal of Zoology 32: 287-292. https://doi.org/10.1080/03014223.2005.9518420

MichalCZYK Ł. \& KACZMAREK Ł. 2010. - Description of Doryphoribius dawkinsi, a new species of Tardigrada (Eutardigrada: Hypsibiidae) from the Costa Rican highlands, with the key to the genus Doryphoribius. Zootaxa 2393: 46-58. https://doi org/10.5281/zenodo.193905

MiCHALCZYK Ł. \& KACZMAREK Ł. 2013. - The Tardigrada Register: a comprehensive online data repository for tardigrade taxonomy. Journal of Limnology 72(S1): 175-181. https://doi.org/10.4081/ jlimnol.2013.s1.e22

MiHELČIČ F. 1953. - Contribucion al conocimiento de los tardigrados con especial consideracion de los tardigrados de Osttirol (II). Anales de Edafologia y Fisiologia Vegetal 12 (5): 431-479.

Mironov S. V., DABERT J. \& DABERT M. 2012. - A new feather mite species of the genus Proctophyllodes Robin, 1877 (Astigmata: Proctophyllodidae) from the Long-tailed Tit Aegithalos caudatus (Passeriformes: Aegithalidae): morphological description with DNA barcode data. Zootaxa 3253: 54-61.

MoreK W., Stec D., GąsioreK P., Schill R. O., KaczMareK Ł. \& MiCHALCZYK Ł. 2016a. - An experimental test of tardigrade preparation methods for light microscopy. Zoological Journal of the Linnean Society 178: 785-793. https://doi.org/10.1111/zoj.12457

Morek W., Gąsiorek P., Stec D., Blagden B. \& MichalczyK Ł. 2016b. - Experimental taxonomy exposes ontogenetic variability and elucidates the taxonomic value of claw configuration in Milnesium Doyère, 1840 (Tardigrada: Eutardigrada: Apochela). Contributions to Zoology 85 (2): 173-200.

MoreK W., STEC D., GąiOReK P., SuRMaCZ B. \& MichalczyK Ł. 2019. - Milnesium tardigradum: the first integrative study of inter-population variability in a tardigrade species. Journal of Zoological Systematics and Evolutionary Research 57: 1-23. https:// doi.org/10.1111/jzs. 12233

MORGAN C. 1976. - Studies on the British tardigrade fauna: some zoogeographical and ecological notes. Journal of Natural History 10: 607-632. https://doi.org/10.1080/00222937600770491

Møbjerg N., Jørgensen A., EibYe-Jacobsen J., Halberg K. A., Persson D. \& KRISTENSEN R. M. 2007. - New records on cyclomorphosis in the marine eutardigrade Halobiotus crispae (Eutardigrada: Hypsibiidae). Journal of Limnology 66 (1): 132140. https://doi.org/10.4081/jlimnol.2007.s1.132

MurraY J. 1911. - Clare Island Survey. 37: Arctiscoida. Proceedings of the Royal Irish Academy 31 (37): 1-16.

Nelson D. R. \& MCGLothlin K. L. 1996. - A new species of Calohypsibius (Phylum Tardigrada, Eutardigrada) from Roan Mountain, Tennessee-North Carolina, U.S.A. Zoological Journal of the Linnean Society 116: 167-174. https://doi.org/10.1006/ zjls.1996.0014

Nelson D. R., Guidetti R. \& Rebecchi L. 2015. - Phylum Tardigrada. Academic Press. Thorp and Covich's Freshwater Invertebrates, 1: Chapter 17: 347-380. 
Pilato G. 1969a. — Evoluzione e nuova sistemazione degli Eutardigrada. Bolletino di Zoologia 36: 327-345.

Pilato G. 1969b. - Su un interessante Tardigrado esapodo delle dune costiere siciliane: Hexapodibius micronyx n. gen. n. sp. Bollettino delle sedute dell'Accademia Gioenia di Scienze naturale Catania, Serie IV9 (9): 619-622.

Pilato G. 1981. - Analisi di nuovi caratteri nello studio degli Eutardigradi. Animalia 8: 51-57.

Pilato G. 1989. - Phylogenesis and systematic arrangement of the family Calohypsibiidae Pilato, 1969 (Eutardigrada). Zeitschrift für zoologische Systematik und Evolutionsforschung 27: 8-13.

PILATO G. 1998. - Microhypsibiidae, new family of eutardigrades, and description of the new genus Fractonotus. Spixiana 21 (2): 129-134.

Pilato G. \& Beasley C. W. 1987. — Haplohexapodibius seductor $\mathrm{n}$. gen. n. sp. (Eutardigrada, Calohypsibiidae) with remarks on the systematic position of the new genus. Animalia 14 (1-3): 65-71.

Pilato G. \& Binda M. G. 2010. — Definition of families, subfamilies, genera and subgenera of the Eutardigrada, and keys to their identification. Zootaxa 2404: 1-54.

Pilato G., ClaXton S. \& Binda M. G. 1989. — Tardigrades from Australia II. The evaluation of Calohypsibius ornatus (Richters, 1900) caelatus (Marcus, 1928) as a valid species and description of Minibiotus fallax n. sp. (Eutardigrada). Animalia 16: 21-27.

Rambaut A., SuChard M. A., XIE D. \& DRUMmOND A. J. 2014. Tracer v1.6. Available from http://beast.bio.ed.ac.uk/Tracer

RichTERs F. 1900. — Beiträge zur Kenntnis der Fauna der Umgebung von Frankfurt a. M. Bericht der Senckenbergischen Naturforschenden gesellschaft in Frankfurt am Main 21-44.

RiChTERS F. 1926. - Tardigrada, in Handbuch der Zoologie, de Gruyter, Berlin and Leipzig, 3: 58-61.

RonQuisT F. \& HuelsenBECK J. P. 2003. - MrBayes 3: Bayesian phylogenetic inference under mixed models. Bioinformatics 19 (12): 1572-1574.

Sands C. J., McInnes S. J., Marley N. J., Goodall-Copestake W., CONVEY P. \& Linse K. 2008. - Phylum Tardigarda: an "individual” approach. Cladistics 24: 1-18. https://doi.org/10.1111/ j.1096-0031.2008.00219.x

Schuster R. O., Nelson D. R., Grigarick A. A. \& Christenberry D. 1980. - Systematic criteria of the Eutardigrada. Transactions of the American Microscopical Society 99: 284-303.
STAMATAKIS A. 2014. - RAxML version 8: a tool for phylogenetic analysis and post-analysis of large phylogenies. Bioinformatics 30: 1312-1313. https://doi.org/10.1093/bioinformatics/btu033 Stec D., Smolak R., KaczmareK Ł. \& MichalczyK Ł. 2015. An integrative description of Macrobiotus paulinae sp. nov. (Tardigrada: Eutardigrada: Macrobiotidae: hufelandi group) from Kenya. Zootaxa 4052 (5): 501-526. https://doi.org/10.11646/ zootaxa.4052.5.1

Stec D., Gąsiorek P., MoreK W., Kosztyła P., ZaWierucha K., Michno K., KaczmareK Ł., Prokop Z. M. \& MichalczyK Ł. 2016. - Estimating optimal sample size for tardigrade morphometry. Zoological Journal of the Linnean Society 178: 776-784. https://doi.org/10.1111/zoj.12404

STEC D., MoreK W., GąsioreK P. \& MichalczyK Ł. 2018. Unmasking hidden species diversity within the Ramazzottius oberhaeuseri complex, with an integrative redescription of the nominal species for the family Ramazzottiidae (Tardigrada: Eutardigrada: Parachela). Systematics and Biodiversity 16 (4): 357-376. https://doi.org/10.1080/14772000.201 8.1424267

Thulin G. 1911. - Beitage zur Kenntnis der Tardigradenfauna Schwedens. Arkiv for Zoologi 7 (16): 1-60.

ThuliN G. 1928. - Über die phylogenie und das system der tardigraden. Hereditas 11: 207-266.

Weenicz W., Grohme M. A., Kaczmarek Ł., Schill R. O. \& FroHME M. 2011. - ITS-2 and 18S rRNA data from Macrobiotus polonicus and Milnesium tardigradum (Eutardigrada, Tardigrada). Journal of Zoological Systematics and Evolutionary Research 49(S1): 34-39. https://doi.org/10.1111/j.14390469.2010 .00595 .x

White T. J., Bruns T., LEE S. \& TAYLOR J. 1990. - PCR protocols: a guide to methods and application. Academic Press, San Diego, California, 315-322 p.

ZaWierucha K., Kolicka M., Takeuchi N. \& KaczmareK $\succeq$. 2015. - What animals can live in cryoconite holes? A faunal review. Journal of Zoology 295: 159-169. https://doi.org/10.1111/ jzo. 12195

ZELLER C. 2010. - Untersuchung der Phylogenie von Tardigraden anhand der Genabschnitte 18S rDNA und Cytochrom c Oxidase Untereinheit 1 (COX I). MSc Thesis, Technische Hochschule Wildau, Wildau, $105 \mathrm{p}$. 